\title{
Development of a conceptual framework for the management of biodiversity and ecosystem services in the Mexican Caribbean
}

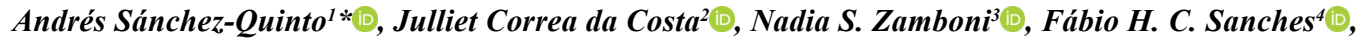

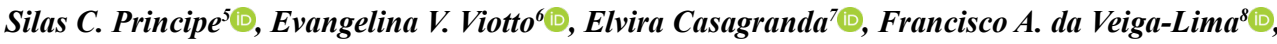 \\ Bianca Possamai ${ }^{9}$ \& Larisse Faroni-Perez $^{10}[0$ \\ ${ }^{1}$ Universidad Nacional Autónoma de México, Posgrado en Ciencias del Mar y Limnología, Ciudad de México, México. \\ ${ }^{2}$ Universidade Federal de Santa Catarina, Departamento de Geociências, Laboratório de Gestão Costeira Integrada, \\ Florianópolis, SC, Brasil. \\ ${ }^{3}$ Universidade Federal do Rio Grande do Norte, Departamento de Ecologia, Av. Salgado Filho, s/n, 59078-970, Natal, \\ RN, Brasil. \\ ${ }^{4}$ Universidade Federal de São Paulo, Instituto do Mar, Laboratório de Ecologia e Gestão Costeira, 11070-100, Santos, \\ SP, Brasil. \\ ${ }^{5}$ Universidade de São Paulo, Instituto Oceanográfico, Laboratório de Biologia Recifal, São Paulo, SP, Brasil. \\ ${ }^{6}$ Centro de Investigación Científica y de Transferencia Tecnológica a la Producción - Consejo Nacional de \\ Investigaciones Cientificas y Técnicas, España 149, Diamante, Entre Ríos, Argentina. \\ ${ }^{7}$ Universidad Nacional de Tucumán, Instituto de Ecología Regional - Consejo Nacional de Investigaciones \\ Cientificas y Técnicas, CC 34, 4107, Yerba Buena, Tucumán, Argentina. \\ ${ }^{8}$ Universidade Federal de Santa Catarina, Laboratório de Gestão Costeira Integrada, Programa de Pós-Graduação \\ em Oceanografia, Florianópolis, SC, Brasil. \\ ${ }^{9}$ Universidade Federal do Rio Grande, Instituto de Oceanografia, Av. Itália km 8, 96203-900, Rio Grande, RS, Brasil. \\ ${ }^{10}$ Universidade Federal de Juiz de Fora, Instituto de Ciências Biológicas, Departamento de Biologia, 36036-900, \\ Juiz de Fora, MG, Brasil. \\ "Corresponding author: Andrés Sánchez-Quinto,e-mail: guitox@msn.com
}

SÁNCHEZ-QUINTO, A., COSTA, J.C., ZAMBONI, N.S., SANCHES, F.H.C., PRINCIPE, S.C., VIOTTO, E.V., CASAGRANDA, E., VEIGA-LIMA, F.A., POSSAMAI, B., FARONI-PEREZ, L. Development of a conceptual framework for the management of biodiversity and ecosystem services in the Mexican Caribbean. Biota Neotropica 20(suppl. 1): e20190901. https://doi.org/10.1590/1676-0611-BN-2019-0901

\begin{abstract}
Coral reefs and mangroves support rich biodiversity and provide ecosystem services that range from food, recreational benefits and coastal protection services, among others. They are one of the most threatened ecosystems by urbanization processes. In this context, we developed a conceptual framework for the management of biodiversity and ecosystem services for these coastal environments. We based our workflow on two sections: "Information base" and "Governance" and use the Puerto Morelos Coastal region as a case study for coastal protection. Puerto Morelos is between two of the most touristic destinations of Mexico (Playa del Carmen and Cancun) that has experienced an increase of population in the past four decades resulting in an intensification of multiple threats to its ecosystems. We characterized the two ecosystems with a "Management Units" strategy. An expert-based ecosystem services matrix was also described in order to connect mangroves and coral reef ecosystems with the multiple beneficiaries. Then an ecosystem model (conceptual model and Global Biodiversity model) was developed. The conceptual model was useful in understanding the interplay processes between systems regarding the ecosystem service of "Coastal Protection". The Global Biodiversity model evidenced the human-induced shifts in the biodiversity for mangrove and coral reefs ecosystems. Also, a projection for 2035 of "best" and "worst" scenarios was applied using GLOBIO3. A DPSIR conceptual framework was used to analyze environmental problems regarding ecosystem services maintenance. Finally, we evaluated a set of policies associated with these ecosystems that favor coastal protection integrity. This framework facilitates the identification of the most relevant processes and controls about the provision of coastal protection service. It can also be useful to better target management actions and as a tool to identify future management needs to tackle the challenges preventing more effective conservation of coastal environments.
\end{abstract}

Keywords: Ecosystem services; Framework; Future scenarios; Marine; Public policies. 


\title{
Desenvolvimento de um roteiro conceitual para a gestão da biodiversidade e dos serviços ecossistêmicos no Caribe mexicano
}

\begin{abstract}
Resumo: Recifes de coral e manguezais possuem rica biodiversidade e fornecem serviços ecossistêmicos, tais como, alimento, recreação, proteção costeira, entre outros. Esses ecossistemas encontram-se entre os mais ameaçados pelos processos de urbanização. Nesse contexto, desenvolvemos um roteiro conceitual para a gestão da biodiversidade e dos serviços ecossistêmicos desses ambientes costeiros. Organizamos nossa sequência de passos de trabalho em duas seções: "Base de informações" e "Governança" e usamos a região costeira da cidade de Puerto Morelos (México) como um estudo de caso para analisar o serviço de proteção de costa. Puerto Morelos encontra-se entre dois dos destinos mais turísticos do México (Playa del Carmen e Cancún), e portanto sua população vem aumentando nas últimas quatro décadas, resultando na intensificação de múltiplas ameaças para os ecossistemas. Primeiramente, caracterizamos os dois ecossistemas identificando-os como "Unidades de Gestão", detalhando seus principais componentes e processos. Através de uma "Matriz de serviços ecossistêmicos", construída com base na opinião de especialistas, foram sistematizados os principais serviços ecossistêmicos prestados pelos manguezais e recifes de corais aos múltiplos beneficiários. Em seguida, foi desenvolvida uma modelagem do sistema (e ecossistemas) através de sua representação na forma de um modelo conceitual e um modelo numérico de Biodiversidade Global. O modelo conceitual facilitou a compreensão dos processos de interação entre sistemas em relação ao serviço "Proteção Costeira”. O modelo numérico evidenciou as mudanças induzidas pelo homem na biodiversidade dos ecossistemas de manguezal e recifes de coral. Além disso, uma projeção dos cenários "melhor" e "pior" foi desenvolvida para 2035 usando GLOBIO3. A Estrutura conceitual DPSIR foi aplicada para analisar problemas ambientais relacionados à manutenção dos serviços ecossistêmicos. Finalmente, avaliamos um conjunto de políticas públicas associadas a esses ecossistemas e que favorecem a integridade da proteção costeira. Portanto, o roteiro facilitou a identificação dos principais processos e controles para a provisão de um serviço ecossistêmico. Além disso, pode ser útil para direcionar melhor as ações de gerenciamento, bem como, uma ferramenta para identificar necessidades futuras de planejamento e gestão para enfrentar desafios que permitam uma conservação mais eficaz dos ambientes costeiros.
\end{abstract}

Palavras-chave: Cenários futuros, Marinho, Políticas públicas; Roteiro; Serviços ecossistêmicos.

\section{Introduction}

Coastal and marine ecosystems are the most productive environments on the planet (MEA 2005) and are also the most threatened by the urbanization process. It is estimated that about one-third of mangrove forests and one-tenth of coral reefs in the world have been lost (Brown 2006). The list of ecosystem services provided by these environments is extensive (see Barbier et al. 2008, Liquete et al. 2013, Barbier 2016, Guannel et al. 2016) and includes water, food, climate regulation, nutrient cycling and different recreational, spiritual and aesthetic benefits (MEA 2005, TEEB 2010a, TEEB 2010b, Diaz et al. 2018). It is essential to understand the effects of the urbanization process on such relevant areas given that these are uniquely productive and biodiverse ecosystems providing ecosystem services to support human well-being.

The 'Ecosystem Services' concept has evolved over the years with definitions on either the ecological basis and the socio-economic uses (Granek et al. 2010). According to MEA (2005), it can be defined as "benefits that people derive from ecosystems". It also can be defined as the main benefits (e.g. services, materials, provision) that the ecosystem provides to the socio-economic activities that are dependent on it. In order to manage and to conserve the ecosystems (and their services), incorporating both conservation and development, Ecosystem-Based Management (EBM) has been proposed as a valuable strategy (Barbier et al. 2008). This approach focuses on ecosystem services since they reflect social goals, values, desires, and benefits. The inclusion of ecosystem services into holistic management strategies improves management by better capturing the diversity of positive and negative human-natural interactions and making explicit benefits to society (Kelble et al. 2013).
The EBM approach deals with the management and the sustainability of human activities to maintain the ecosystem services generated by coastal ecosystems (McLeod \& Leslie 2009, Dasí 2011, Arkema et al 2015).

The anthropogenic threats that result from different human activities are numerous and particularly harmful to coastal ecosystems, which are influenced by activities on land (terrestrial and freshwater), along the coasts, and in the ocean (Halpern et al. 2008). According to Halpern et al. (2008), when management planning and implementation within a sector considers the effects of an activity on a habitat or other ecosystem components, it is only to the overall goals for that sector. However, a holistic view of multiple impacts affecting the entire ecosystem is necessary for effective management of several ecosystem services.

Coastal ecosystem responses to climate change and anthropic stressors are extensively studied, showing changes in ecosystems landscape and biodiversity (Duke et al. 2007, Barbier et al. 2008, Feller et al. 2017). However, management actions on the whole coastal landscape have been infrequent (Hoegh-Guldberg et al. 2008, McClanahan et al. 2015, Weijerman et al. 2015). Accordingly, an EBM framework is useful to mitigate the current and potential impacts of urbanization on coastal ecosystems. Mangroves and coral reefs, for example, are coastal systems that are impacted by overexploitation of fishery stocks, habitat degradation by human activities, SCUBA diving and boating, aquaculture, water pollution and eutrophication, land conversion, invasive species and the effects of climate change (Figure 1) (FAO 2008, Feller et al. 2017, IUCN 2018, Pelage et al. 2018). These drivers threaten the socioeconomic sustainability of activities derived from the coastal ecosystem services and could cause, in some cases, severe ecological losses at different spatio-temporal scales (Duke et al. 2007, Feller et al. 2017). 


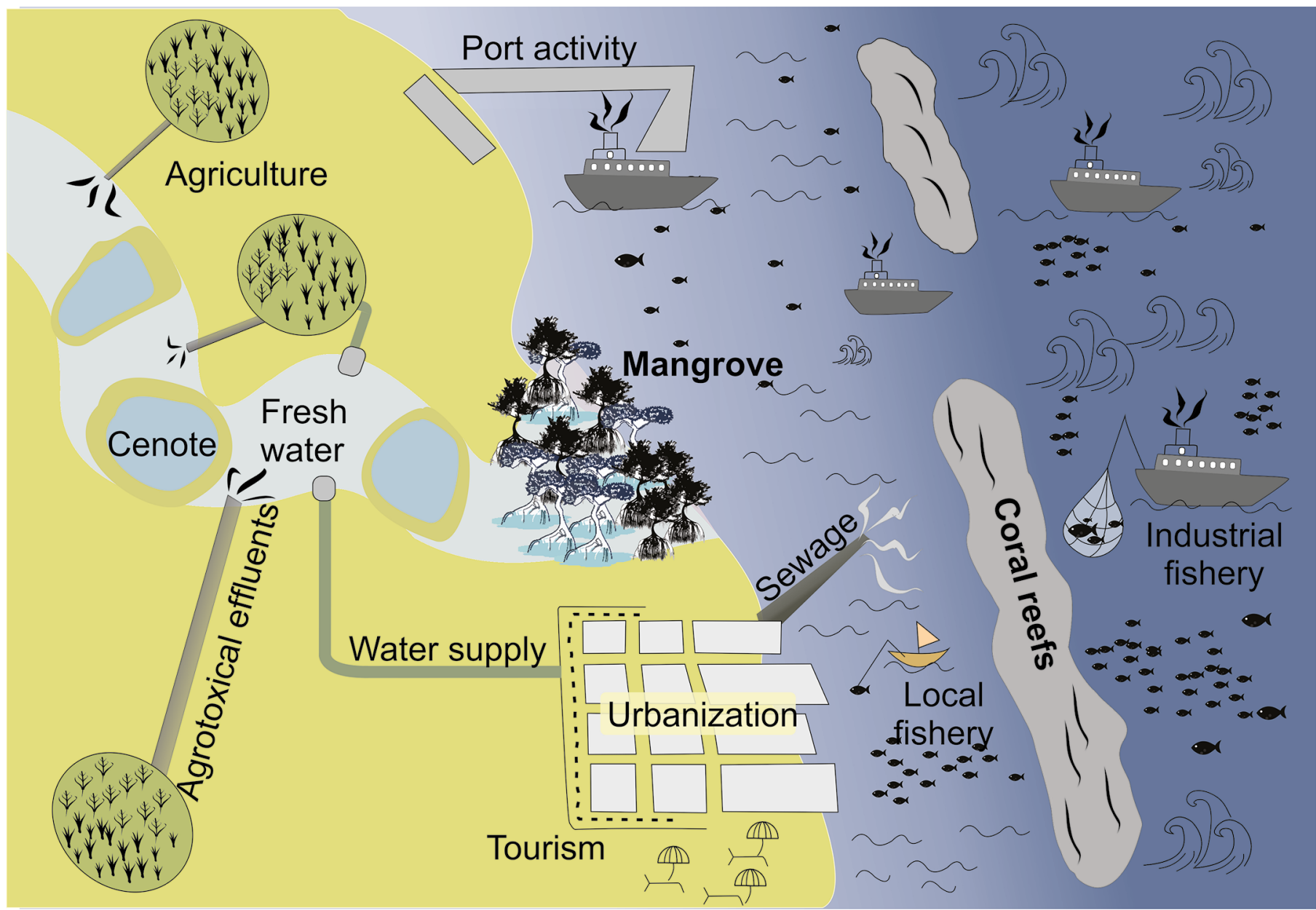

Figure 1. Representation of the anthropogenic impacts on coastal ecosystems. This scheme is based in Puerto Morelos, Mexico system and its human activities. The main anthropogenic impacts in Puerto Morelos are: sewage, urbanization (tourism, land-use change), fisheries and port activities.

In this context, the principles of EBM have often been defined and applied to these ecosystems to aid their conservation and optimize decision-making strategies (Yáñez-Arancibia et al. 2013). EBM may help to maintain ecosystem services by identifying possible scenarios that can be adopted by policy/decision-makers thereby encouraging sustainable development.

In order to apply and describe some insights of the EBM strategy, we used the case study of Puerto Morelos, a town in the south-east of Mexico. This town is located in the Mexican Caribbean, a popular tourist destination experiencing a rapid urbanization process. In Puerto Morelos is located the national park Parque Nacional Arrecife de Puerto Morelos (PNAPM), which hosts a mosaic of ecosystems (such as wetlands, seagrass, coastal lagoons, coral reefs, and mangroves), resulting in one of the most biodiverse regions of the Caribbean (Miloslavich et al. 2010). Mexico has a legal framework for coastal ecosystems that include laws, official norms, and programs that establish the regulations for the conservation, sustainable use and restoration of coastal wetlands in mangrove areas. For the coral reefs ecosystems, there are guidelines promoted by the Management Program of Puerto Morelos National Park (INAFED 2019). There is also the International MRS Leadership Program for sustainable use of resources, that through the Safeguard
Zone, called Coral Reefs of the Gulf of Mexico and the Mexican Caribbean, encourages partial reef protection, since hydrocarbon exploration and extraction activities are prohibited (Costanza et al. 2014, Perez-Cervantes et al. 2017). In addition, the production of technical and scientific data about components and processes (i.e. biological, ecological, social and economic) for coral reef and mangrove ecosystems across the Caribbean has increased exponentially in recent years.

Given the above statements, it becomes increasingly necessary to apply scenarios for identifying future strategies capable of promoting conservation actions, sustainable use and avoid habitat degradation. Additionally, it is pivotal to assess whether the changes in biodiversity and ecosystem services, driven by socio-economic pressures, are covered by robust protection policies. In this context, this study aims to design and describe a pathway to develop an EBM framework for coastal ecosystems. This article examines practical experimentation of the intersections between science and policies for the mangroves and coral reefs in Puerto Morelos, Mexico. We use available data for strengthening policy formulation and implementation by decisionmakers. This could help ensure the conservation and sustainable use of ecosystem services in coastal regions, enhancing the ecological relevance and human well-being. 


\section{Material and Methods}

\section{Study area}

The case study was performed for Puerto Morelos, in the north of Quintana Roo state, Mexico. This town is located between Cancun and Playa del Carmen, which are the most popular coastal tourist destinations of Mexico in the Caribbean (Coronado et al. 2007) (Figure 2). Puerto Morelos retains part of its original features as a fishing village. In addition, the massive tourism it received in the recent years, impacts from urbanization, agriculture and drainage are already noticeable (Figure 1). The coral reef barrier is a touristic attraction and is protected by the Parque Nacional Arrecife de Puerto Morelos (PNAPM) (located

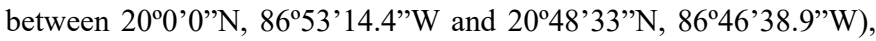
which covers an area of 9066 ha (SEMARNAT 2016). The Puerto Morelos reef extends parallel to the coast with three structural zones; (i) The reef lagoon, between the reef and the coast, with the bottom mainly covered by seagrass macroalgae and calcareous sand; ii) The reef ridge, between the lagoon area and the reef, covering the larger area with scleractinian coral diversity, and areas with grassland and seaweed; and, iii) The frontal reef, found in shallow waters, covered by corals and coral rubble and dominated by the species Acropora palmata (Lamarck 1816) (Jordan-Dahlgren 1979, Sánchez-Quinto \& Falcon 2019). Economically, around $60 \%$ of the local population depends directly or indirectly on the reef's ecosystem benefits services.
Among the various ecosystem services that coral reefs provide, the economic activities related to the categories of cultural and supporting ecosystem services stand out the most. The main users of these services are nautical tourists (looking to dive, do snorkeling and fishing, etc.) and fishermen (Figure 1).

Due to the location and natural attractions, Puerto Morelos' population has been growing rapidly. Between 1980 and 2010, the population has increased from 222 to 9188 inhabitants (Jordán-Dahlgren \& Rodriguez-Martinez 1998, Carabias-Lillo 2000, INEGI 2010, Gomez 2020), and currently reached approximately 37000 inhabitants (INAFED 2019). This fast population increase is not always followed by basic infrastructure services (such as sewage treatment, land use regulation, etc.) and could lead to coastal ecosystems degradation. The sewage treatment is limited and most of the population are served by septic tanks. The remaining waste is taken to one of the three primary treatment plants where the water is treated and pumped about $60 \mathrm{~m}$ deep into the soil (Hernández-Terrones et al. 2011).

The two villages (coastal/touristic and urban/local population zones) of Puerto Morelos are surrounded by coastal vegetation including mangroves, and the increasing population threatens this ecosystem as well. Tourism has increased so quickly in recent years that hotel capacity grew from 3638 to 5500 rooms between 2008 and 2018, reaching more than 7000 rooms by 2020 (Comunicación Social de Puerto Morelos 2019, Gomez 2020).
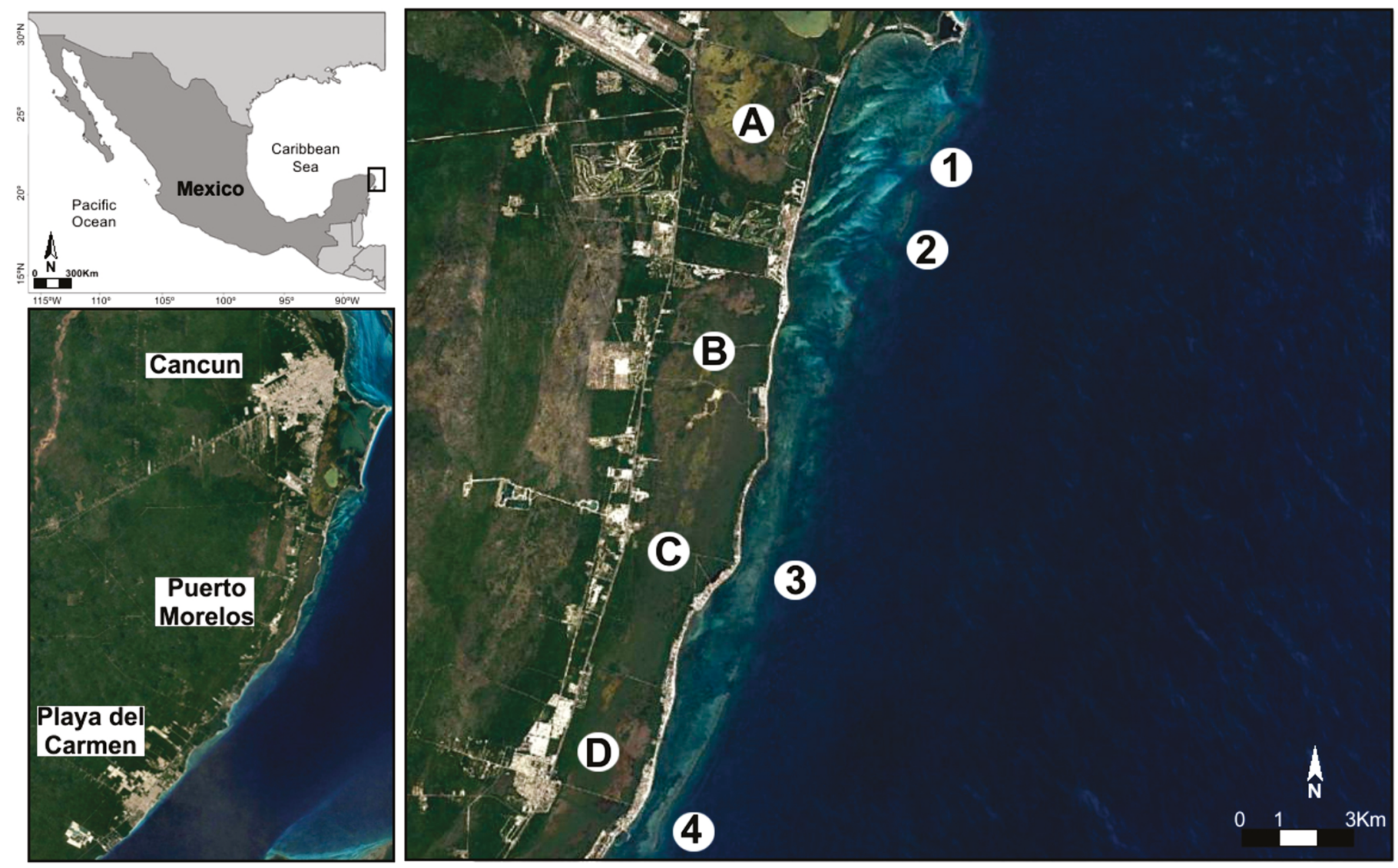

Figure 2. Study area. Upper left panel: Mexico with a highlight in the study area; Bottom left panel: Satellite Image of Puerto Morelos showing its proximity with two main touristic localities (Cancun and Playa del Carmen); and Right panel: Location of Puerto Morelos, Quintana Roo in the Mexican Caribbean, where (A), (B), (C) and (D) show the areas used in the GLOBIO3 model to calculate the vegetation cover. The numbers represent the location of the coral reef areas: (1) Limones, (2) Bonanza, (3) Tanchacte, and (4) Jardines. Source: Google Earth (Landsat/Copernicus). 
Moreover, it is expected that the construction of 2000 residential units and eight lodging centers nearby a protected land, constituted for forests of red mangrove (Rhizophora mangle) (Linnaeus 1753), button mangrove (Conocarpus erectus) (Linnaeus 1753) and chit palms (Thrinax radiata) (Lodd 1830) (CONABIO-CONANP-TNC-Pronatura 2007) will start soon. Moreover, similar to the urban areas described, most hotels do not have proper sewage treatment with the larger hotels pumping the treated water into the aquifer $(70-100 \mathrm{~m})$.

\section{Practical experimentation strategy}

The methodological approach used for Puerto Morelos in this study was partially based and adapted from Asmus et al. (2018). In order to establish an ecosystem information base that supports integrated management, our method consisted of four sections: 1) the identification of ecosystems as management units; 2 ) the identification of the ecosystem services (ESM); 3) the ecosystem modeling (Conceptual model and Global Biodiversity model); and 4) the identification of the management sectors (DPSIR and Policy assessment). (Figure 3).

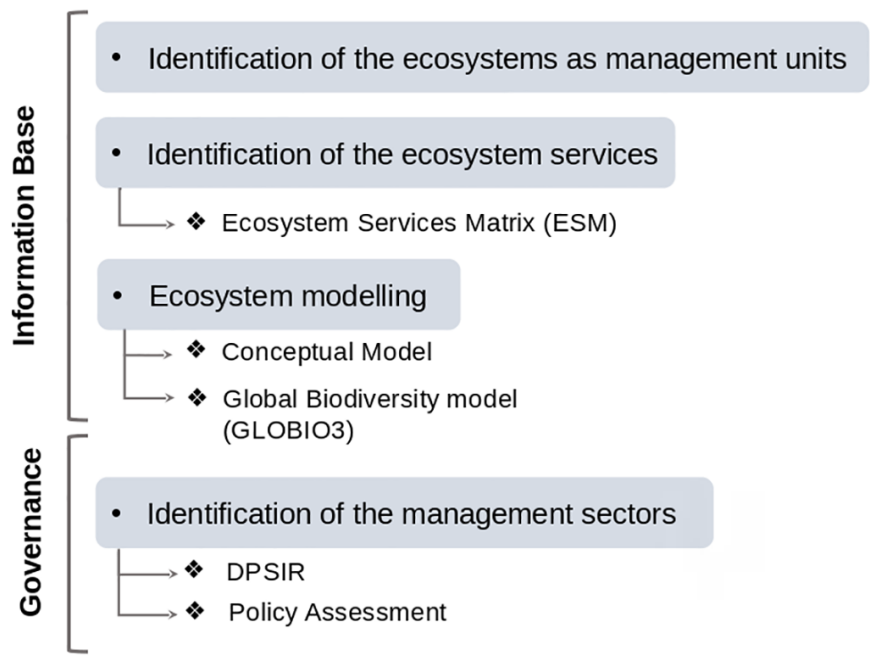

Figure 3. Methodological sections adapted for Puerto Morelos study case, modified from Asmus et al. (2018), . Within the information base section we followed: the identification of the ecosystems as management units; the identification of the ecosystem services (ESM); and the ecosystem modelling (Conceptual model and Global Biodiversity model). Within the Governance section, we included the identification of the management sectors (DPSIR and Policy assessment).

In all sections, a comprehensive bibliographic review was performed to guarantee the theoretical basis, revealing the concepts and definitions that guided the scope of the investigation and results interpretation. The main ecosystem service provided by mangroves and coral reefs identified was "Coastal Protection". These two ecosystems protect coastal areas and their population from the effects of waves, storms, rising seas, among others. Through these sections, the elements in the ecosystem information base are defined to understand the ecosystems and the different connections between their main components and processes responsible for coastal protection. The last two subsections (DPSIR and Policy Assessment) bring the elements of management and governance that result from an analysis of the ecosystem information base, together with assessments of existing policies for ecosystem protection and management. Nevertheless, the definition of values and qualities from Asmus et al. (2018) were omitted given the theoretical scope of this proposal, as we have not worked directly with the social actors to understand their perception of values in relation to services that might benefit their local communities.

\subsection{Identification of ecosystems as "Management Units"}

To identify and characterize the focal coastal ecosystems (i.e. mangrove and coral reefs) as management units, we applied a strategy to capture the knowledge of different experts on a particular topic, a commonly used procedure to fill gaps in scientific research (Krueger et al. 2012, Martin et al. 2012, Nordlund et al. 2016). We used this approach to acquire information on ecosystems and the different aspects related to socioeconomic activities (ecosystem services, uses and benefited actors), as well as initiatives and strategies for coastal management in Puerto Morelos.

\subsection{Ecosystem Services Matrix (ESM)}

Following the identification of ecosystems as "management units", we developed an ESM. The ESM was developed in order to visualize the connection between mangrove and coral reef ecosystems and their diverse beneficiaries, taking into account the activities developed in each ecosystem and the use of ecosystem services for human well-being. First, we identified the different services provided by each ecosystem, recognizing its corresponding ecosystem service category based on the Millennium Ecosystem Assessment (MEA 2003) classification. The four categories are: 1. Support: those required for the maintenance of other ecosystem services, such as nutrient cycling and ecological corridors; 2. Provision: products obtained from ecosystems (such as food, wood and medicinal products); 3 . Regulation: related to the regulatory characteristics of ecosystems (such as air quality maintenance, erosion control and climate); and, 4. Cultural: related to human values and behaviors linked to ecosystems (such as contemplative and spiritual values and social relations). Second, the various benefits and beneficiaries were listed. Finally, all the information collected was organized in a table, allowing for the identification of the different ecosystem services from mangroves and coral reefs and their importance to people in the study area.

\subsection{Conceptual model}

Once the management units were characterized and the main ecosystem service identified, we developed a conceptual model (Figure 4). The diagram of the conceptual model was drafted to understand the interplay of the coastal processes, namely, the ecosystem services of "Coastal Protection" and interactions with the ecosystems and the environmental and socio-economic components. The structure of the conceptual model allows an understanding of the system in its organizational base, where several simultaneous processes occur. After mapping the ecosystems and their services, as well as the actors involved, and how they interact with the ecosystems, the conceptual model was also used to understand the methods developed in this proposal, by describing the processes through a diagram (Figure 4), as follows: 


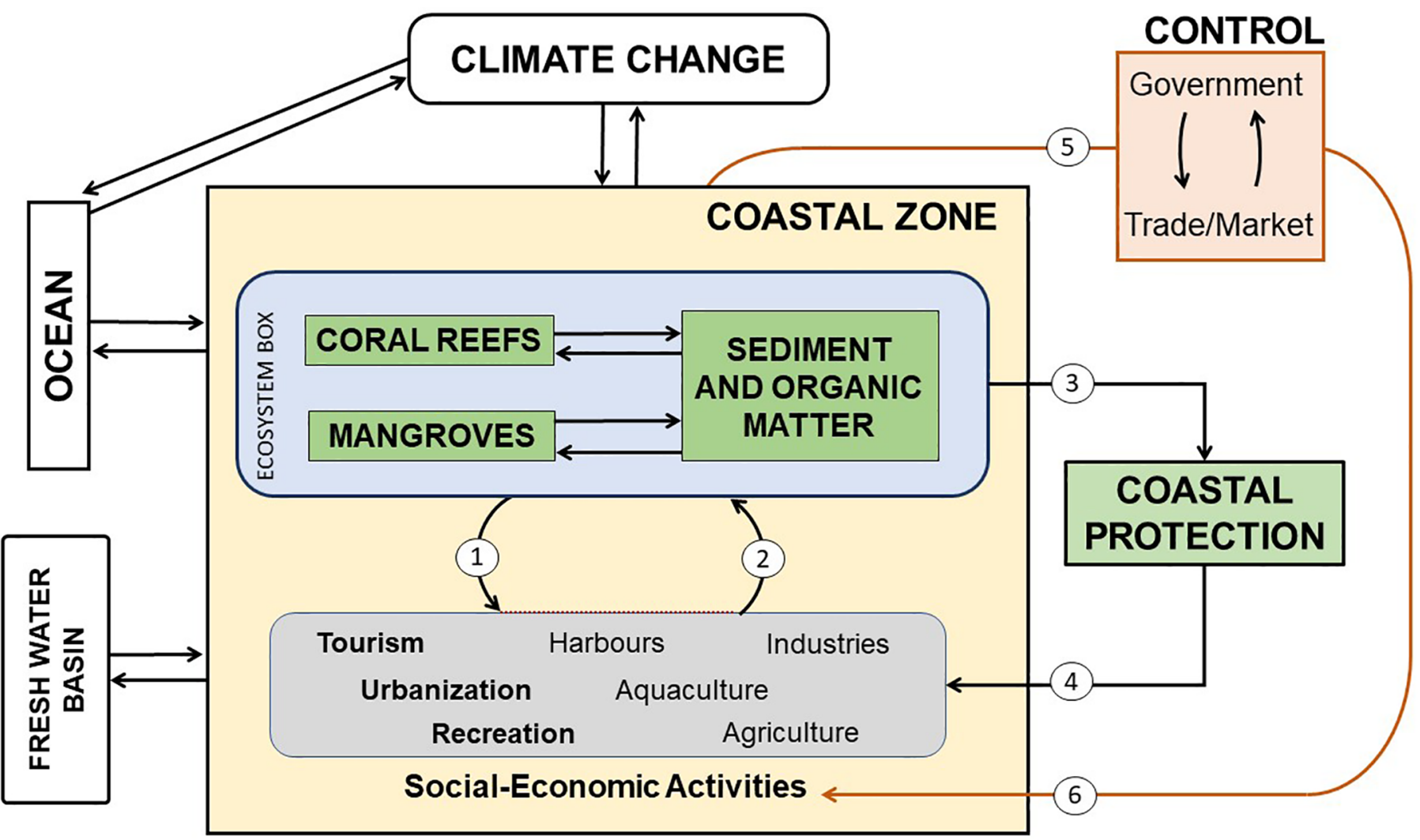

Figure 4. Conceptual model representing the main components (boxes) and processes (numbered circles), based on the coastal protection, as the main ecosystem service in analysis in Puerto Morelos, Mexico. Six processes within the Coastal Zone (orange box) were identified (black arrows indicate direct interaction). Process 1: Ecosystem services provided by mangroves and coral reefs to society (blue box). Process 2: Pressures and the drivers affecting mangroves and coral reefs (grey box). Processes 3 and 4: The connection between the ecosystems and the activities in the coastal zone that directly affects the coastal protection service (green box). Processes 5 and 6: The ecosystem-based information used as a tool to support government management decisions (orange line and orange box) and the creation of new policies aiming the conservation of ecosystems (orange arrow).

Process 1: Refers to services provided by mangroves and coral reefs to society. An Expert-Based Ecosystem Services Matrix, Global Biodiversity model, and DPSIR framework were applied as tools for the characterization of the ecosystems within Puerto Morelos.

Process 2: The activities carried out in the coastal zone can impact ecosystems and thereby affect (even causing loss) on the "coastal protection" service. Therefore, we identified some of the main pressures and drivers affecting mangroves and coral reefs. Despite the fact that climate change is an important driver, in this study we focused on direct human-effects (mainly the urbanization process) to evaluate how these activities cause pressure in the ecosystems and threaten their services. The DPSIR framework and the GLOBIO model were used to link the current state of the ecosystems with potential future scenarios.

Processes 3 and 4: The connection between the ecosystems and the activities in the coastal zone affects directly the coastal protection service, among others coastal ecosystem services. Hence, to identify these influences on human well-being (benefits and actors benefited), we used an Expert-Based Ecosystem Services Matrix, which provides a qualitative database for the analysis. Moreover, a DPSIR framework, policy assessment and a Global Biodiversity model are crucial to identify the best scenario as possible for maintaining the coastal protection service.

Processes 5 and 6: All the characterization from the Expert-Based Ecosystem Services Matrix, the Global biodiversity model, the DPSIR and policies, were used to obtain the ecosystem-based information.
The policies could be used as a tool to support government management decisions (Process 5). Thus, the government will have the background information to reinforce or enact new policies in order to conserve ecosystems and their ecosystem services (such as coastal protection) (Process 6).

\subsection{Global Biodiversity Model}

The next step was to identify the pressures over the biodiversity of both mangrove and coral reefs ecosystems. For this, we applied the Global Biodiversity model (GLOBIO3; Alkemade et al. 2009) as a proxy for understanding the impacts of ecosystem degradation on the 'Coastal Protection' service by modeling the loss of biodiversity in both ecosystems over a decade and for predicting future scenarios (optimistic and pessimistic) for the next two decades. The mean species abundance (MSA) relative to their abundance in a reference condition is used as an indicator of biodiversity. The MSA computes the average of remaining species abundance in disturbed circumstances in relation to the equivalent in an undisturbed control condition by scaling between one (undisturbed or primary ecosystem) and zero (disturbed ecosystem). The driver of biodiversity loss considered herein for terrestrial ecosystems (mangroves) is land-use change (MSALU). For the coral reefs, we used a similar approach using coral cover change to assess the impacts of human activities on this ecosystem. MSA values are categorized as follows: $0 \leq 0.20$ low; $0.21-0.40$ relatively low; $0.41-0.60$ medium; $0.61-0.80$ relatively high; and $0.81 \leq 1$ high (Trisurat et al. 2010). 
Our framework includes terrestrial (coastal vegetation) and marine (coral reefs) ecosystems. The coastal vegetation was defined as 'mangroves' since mangrove species, such as $R$. mangle, Laguncularia racemosa (Volkmar 1979), Avicennia germinans (Linneo 1764), and $C$. erectus, are the dominant vegetation in the analyzed area. Although occurring in surrounding vegetation in a smaller proportion (evergreen tropical forest) (Vázquez-Lule et al. 2009), we restricted the term naming mangroves as the main terrestrial ecosystem supplier for coastal protection (our target ecosystem service). For analyzing mangroves data, we selected an inland area in front of the reef barrier using Landsat images from Google Earth Professional ${ }^{\rrbracket}$, and determined four adjacent areas of $5 \mathrm{~km}^{2}$ inside the selected inland area (Figure 2). We set the reference condition as 2005 and calculated the total area of mangroves cover (i.e. the undisturbed area) using the polygon tool. Additionally, we considered the other areas with more than $80 \%$ built up disturbed as urbanized, even if it still had some sort of sparse vegetation between constructions, following the same parameters of the GLOBIO3 (Alkemade et al. 2009). To obtain MSA values for each area, we multiplied the total area (in $\mathrm{km}^{2}$ ) of each category (i.e. intact forest or urbanized area) to the corresponding $\mathrm{MSA}_{\mathrm{LU}}$ values from Alkemade et al. (2009) (i.e. vegetated areas - 1.0; built-up areas - 0.05). Both values were then summed and divided by the total area $\left(5 \mathrm{~km}^{2}\right)$, generating a MSA value ranging from 0 to 1 . Cumulative changes were thus computed to the reference condition in 2005 , as well as for the years of 2008, 2011 and 2014.

Concerning the marine system, for the coral reefs we considered the reduction of coral cover in four different areas: Limones, La Bonanza, Tanchacte, and Jardines (Figure 2). GLOBIO3 is designed mainly for terrestrial ecosystems, with an adaptation available for inland water ecosystems (Janse et al. 2015) allowing us to modify some analysis to be useful for marine ecosystems as well.
Instead of analysing satellite images, our proposed modification relied on a meta-analysis of published data on the different areas of coral reef cover in the same years used for mangroves (2005, 2008, 2011, 2014). Therefore, the coral cover was analysed for the same years as mangroves, using data obtained from Banaszek \& Álvarez-Filip (2014) and Álvarez-Filip \& Banaszek (2016).The percentage of area with and without coral cover was also used. To obtain the MSA values for each area, we adapted the resilience index estimated by Ladd \& Collado-Vides (2013) for each of the four sites studied. These indexes applied local empirical data based on broad and local-scale indicators that influence ecological processes, anthropogenic impacts, biological variables and physical variables of coral reefs. These include 'Fishing Pressure', 'Contamination/Pollution ( $\% \mathrm{~N}$ and $\mathrm{N}: \mathrm{P})$ ', 'Land-based Anthropogenic Impacts $\left(\delta^{15} \mathrm{~N}\right)$ ', 'Anthropogenic Physical Impacts (Tourism Intensity)', 'Herbivore Biomass', 'Abundance of Invasive Species', and so on (see Ladd \& Collado-Vides 2013 and the original concept in Maynard et al. 2011). Scores obtained from the resilience index (which ranges from 0 to 100) were weighted from 0 to 1 and assigned into coral-MSA values. We considered the areas with coral cover to have the highest coral-MSA (i.e. 1.0, as those areas are equivalent to an intact forest) and the areas without coral cover were multiplied by the resilience index equivalent to the area of study (Limones: 0.94; La Bonanza: 0.68; Tanchacte: 0.75; and Jardines: 0.82). Thus, values of each coral reef were summed and divided by the total area, resulting in the MSA value for the coral reef.

After modeling values for both terrestrial and marine ecosystems over the last decade, we also generated two future scenarios for both ecosystems. The scenarios were projected to 2035, two decades after the observed values in order to make predictions of optimistic and pessimistic scenarios, and to consider a period where more effective ocean governance is implemented by taking actions to mitigate biodiversity loss (Figure 5).

Current (2005-2014)

Future scenario (2035)

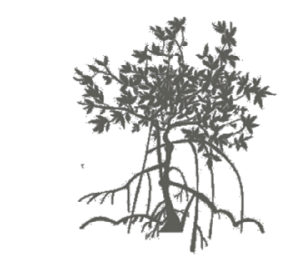

- Population growth

increase

- Land conversion

(urbanization)

- Forest area decrease

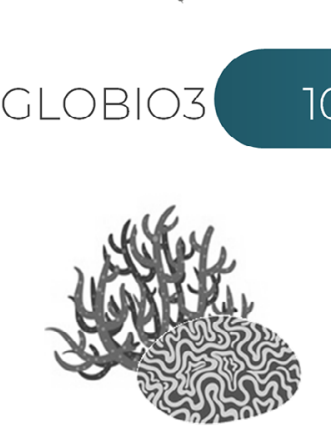

10 years

- Increase in sewage

- Tourism increase

- Strengthening

conservation laws
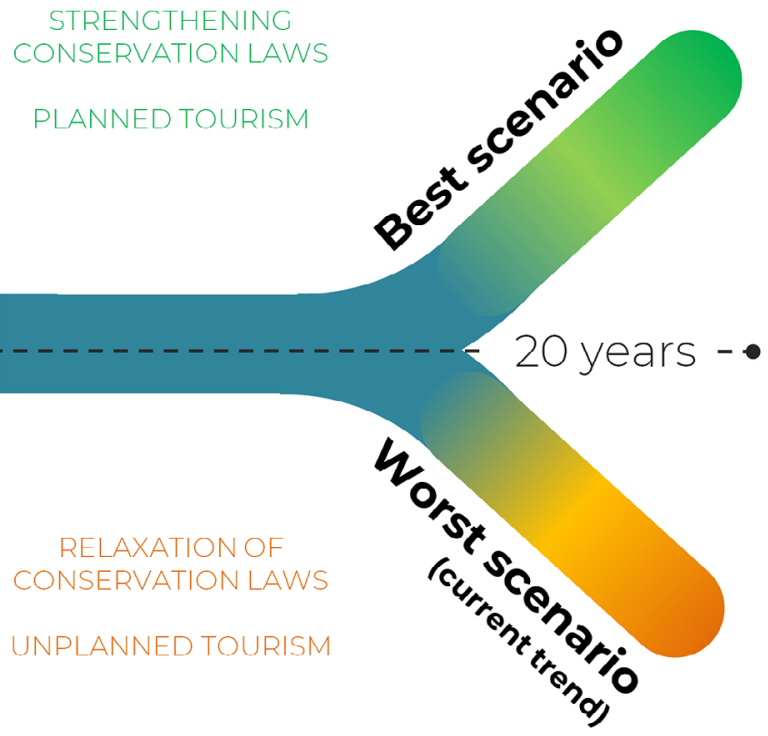

Figure 5. Theoretical past and future scenarios for mangroves and coral reefs in Puerto Morelos. In light grey, besides draw schemes (mangrove and corals) are the "current"conditions (left), representing the changes in vegetation and coral cover for the last 10 years (see GLOBIO3 results). The two future scenarios representing projections for a Best Scenario' (top, in green) in which conservation laws are strengthened and Puerto Morelos acts towards sustainable policies; and a 'Worst Scenario', which is the maintenance of current actual policies (bottom, in reddish). 
Given the above, we projected: (1) the effects of policy implementation for sustainable development (best scenario - 2035-B); and, (2) the effects of maintenance of current policies (worst scenario - 2035-W).

To project the best scenario (2035-B) for mangrove vegetation, we calculated an increase of $10 \%$ of the vegetated area compared to the last assessed year (2014) and calculated the expected MSA to 2035. The National Policy of Seas and Coasts of Mexico includes regulation on the need of reverting the damage inflicted to marine and coastal ecosystems. Furthermore, this is a possible scenario since technology has been developed for mangrove rehabilitation with improved results and reduction of costs (see Dale et al. 2014 for a revision on this theme). We consider that this value could be achieved if conservation policies were applied in the following years (i.e. through mangrove restoration). For coral reefs, we calculated the gain of coral cover in 10 years (from 2005 to 2014) for Limones, which had the highest coral cover recovery (25\%) according to ÁlvarezFilip \& Banaszek (2016). This value was divided by 10 (according to the period 2005-2014), representing an annual cover recovery of $2.5 \%$. We then applied this value of annual coral cover increase in all studied areas for the period of 2015 to 2035, obtaining the coral cover for the best future scenario. We considered the $25 \%$ value due to empirical data occurring in the last decade, that represents a realistic recovery value under compliance of coral reef conservation policies and actions. However, it is important to note that this "best scenario" may be conservative, as a $25 \%$ increase occurred in circumstances of little effort invested for conservation of coral areas in Puerto Morelos. Finally, to project the worst scenario $(2035-\mathrm{W})$ for both mangrove and coral reefs, we calculated the linear regression equation (based on the MSA values from 2005, 2008, 2011 and 2014) and projected the trend to 2035. Finally, we named this scenario 'worst' because our data analysis reveals a trend in relaxation of conservation laws and unsustainable tourism.

\subsection{Drivers - Pressures - State - Impact-Response (DPSIR) framework}

The DPSIR framework was performed in the identification of the management sectors to analyze environmental problems regarding ecosystem services maintenance. DPSIR is a conceptual framework model widely applied to different case studies in management to solve problems involving environmental changes driven by socioeconomic pressures with the required actions to mitigate adverse impact on ecosystem goods and services (Zaldívar et al. 2008, Gari et al. 2015, Patricio et al. 2016). In our specific case study, the DPSIR model was elaborated for "coral reefs" and "mangroves" ecosystems, identifying the socio-economic activities that are direct and/or indirect forces generating transformations of these environments (Tourism/ Recreation, Urbanization, Fishing, Port Activity). The "drivers" were considered as possible activities that substantially affect the coastal environments. The "pressures" were considered as the anthropogenic factors inducing environmental changes. The "state" was considered to be the conditions that generate pressures on each part of the environment. The "impacts" correspond to the negative effects of the pressures in these ecosystems. Finally, "response" encompasses the solutions proposed to mitigate or modulate the effects of the "drivers" in the ecosystems.

\subsection{Policy assessment}

To provide the required knowledge for the governance stage, we first identified and compiled the Mexican government's environmental management tools, including the legal and normative instruments related to the studied ecosystems. These policies were assessed adopting three groups of indicators in which the legal framework were addresses: i) incorporation of ecosystem services approach (defining or not guidelines and actions about coral reefs and coastal vegetation); ii) association with economic activities and land/marine use change (urbanization, ports and navigation, tourism, fisheries); and, iii) attention to climate change effects. We then analyzed the policies related to our study case in three different levels of management: Federal (Mexico), Regional (Quintana Roo State) and Local (Puerto Morelos Municipality). The analysis of the legal framework was focused on policies and tools that directly or indirectly support conservation and sustainable management of marine and coastal areas in Mexico (coral reefs and mangroves as the main target); and/or address anthropogenic and natural drivers of change in these systems.

This evaluation of the legal framework enables support to decisionmaking processes and defines scenarios of conservation policies while identifying gaps in current design of the management instruments. It also assesses possible options to address policy formulation and implementation to further sustainable development.

\section{Results}

The designed pathway to catalyze the development of ecosystembased management framework for coastal ecosystems and applied in the mangroves and coral reefs ecosystems in the National Reef Park of Puerto Morelos is described as follows:

\section{Identification of ecosystems as "Management Units"}

Mangrove forest global distribution occurs in a transition zone between terrestrial (low-lying coastal areas) and marine (inter-tidal zones) ecosystems and are confined between subtropical latitudes, generally delimited by the $20^{\circ} \mathrm{C}$ isotherm of seawater (Alongi 2009). Mangroves are highly productive ecosystems, host a great biological diversity (several species of birds, fish, crustaceans, molluscs, amphibians and others), and provide a wide variety of ecosystem goods and services for human well-being and coastal and marine ecosystems. For instance, mangrove forests provide feeding, shelter and nursery for biodiversity; raw materials (fuel and wood), fishery production supporting, aesthetic and recreation services, flood control, saline intrusion mitigation, erosion control, coastal protection, water quality, and maintenance of natural processes such as sedimentation and responses to sea level changes (Valiela 2001, SEMARNAT 2003, CONABIO 2006). Mexico is the fourth most mangrove-rich country with cumulative percentages of about 741,917 ha (Giri et al. 2011). In turn, the Yucatan Peninsula Region accounts for $55 \%$ ( $423,751 \mathrm{ha})$ of the total mangrove extension. These forests are predominantly composed of four halophyte tree species (tolerant to salinity) (R. mangle, L. racemosa, A. germinans and C. erectus).

Coral reef ecosystems are globally confined between the Tropics of Cancer and Capricorn (Dubinsky \& Falkowski 2011). Coral reefs are marine communities of shallow waters near the coast, dominated by a great diversity of corals, algae, invertebrates, microbes and fishes (Lesser et al. 2018, Sánchez-Quinto \& Falcon 2019). 
They have ecological importance in coastal dynamics by preventing erosion and decreasing the force of waves, as well as being the most effective protection structure against the strong effects of tropical storms and hurricanes. Corals are essential within the ecosystem since they carry out different functions as primary producers, reef builders, filters and predators. Coral reefs also provide several ecosystem services related to breeding, shelter, feeding and reproduction of many species of invertebrates and vertebrates with commercial importance for the Mexican population (Moberg \& Folke 1999, Woodhead 2019). In addition, they provide recreational activities, coastal protection, soil formation, climate mitigation, aesthetic and cultural benefits, among many others. In the Yucatan Peninsula, the distribution of corals is found from Contoy Island to Banco Chinchorro. In the National Reef Park of Puerto Morelos, corals form barrier reefs parallel to the coast (Coronado et al. 2007, Aguilar et al. 2008).

\section{Identification of the Ecosystem Services (Ecosystem Services Matrix)}

The systematization of the collected information into the Ecosystem Services Matrix revealed 16 services provided by mangroves and 14 services by coral reefs (Table 1). The matrix also shows that several social actors are benefited by ecosystem services, ranging from fishermen to local community to pharmaceutical industry.
The highest number of beneficiaries (six) registered was related to the regulation ecosystem services category as the services of "sediment regulation", "hydric balance", "carbon sequestration and storage" and "extreme events mitigation" which encompass benefits such as water quality, flood control, erosion control and coastal protection. These provide extremely important contributions to the sustenance and maintenance of all activities developed inside and adjacent to the study area.

\section{Conceptual model}

The conceptual model shows a fragment of the coastal zone with the presence of ecosystems (coral reefs and mangroves) and different socioeconomic activities (such as: tourism, urbanization, recreation, etc.) (Coastal Zone box) (Figure 4). Although these activities obtain benefits from ecosystems through the provision of several products and services (Process 1), they act as Drivers, affecting the ecosystems and their benefits (Process 2). One of the important services that coral reefs and mangroves provide through their functions (Ecosystem box) is "coastal protection" (Process 3), which facilitates the development of diverse socioeconomic activities and in turn, benefit different social actors (such as: citizens, tourists, fishermen, port workers, among others.) (Process 4).

The ecosystem-based information, including all the ecological and socioeconomic relationships, supports management (Process 5).

Table 1. Ecosystem services matrix for the mangroves and coral reefs in Puerto Morelos, Mexico. The matrix components are based on MEA 2003.

\begin{tabular}{|c|c|c|c|c|}
\hline & MEA & SERVICES & BENEFITS & BENEFITED ACTORS \\
\hline \multirow[t]{3}{*}{ MANGROVES } & Support & $\begin{array}{l}\text { Base for biodiversity, nursery, } \\
\text { nutrient cycling, physical space }\end{array}$ & $\begin{array}{l}\text { Ecosystem itself and fisheries } \\
\text { activities }\end{array}$ & $\begin{array}{l}\text { Fishermen; General and local } \\
\text { community }\end{array}$ \\
\hline & Provision & $\begin{array}{l}\text { Medicinal resources, biomass } \\
\text { production, vegetable fibers, } \\
\text { timber, sediment stock, wood }\end{array}$ & $\begin{array}{l}\text { Raw materials for pharmacy, } \\
\text { fisheries, agriculture and } \\
\text { construction }\end{array}$ & $\begin{array}{l}\text { Pharmaceutical Industry, } \\
\text { Fishermen General and local } \\
\text { community, }\end{array}$ \\
\hline & Cultural & $\begin{array}{l}\text { Landscape, social relationships and } \\
\text { spiritual values }\end{array}$ & $\begin{array}{l}\text { Education, tourism, recreation, } \\
\text { fisheries activities, identity, } \\
\text { contemplation }\end{array}$ & $\begin{array}{l}\text { General and local community, } \\
\text { NGO's, educational institutions }\end{array}$ \\
\hline \multirow{3}{*}{ CORAL REEFS } & Regulation & $\begin{array}{l}\text { Sediments regulation (retention } \\
\text { and export), nutrients and } \\
\text { sediments filtration, hydric } \\
\text { balance, carbon sequestration and } \\
\text { storage, moderation of extreme } \\
\text { events }\end{array}$ & $\begin{array}{l}\text { Water quality; flooding control, } \\
\text { erosion control (shoreline } \\
\text { stabilization), climate control } \\
\text { (mitigation and adaptation); air } \\
\text { quality; coastal protection, storm } \\
\text { protection }\end{array}$ & $\begin{array}{l}\text { General and local community; } \\
\text { Urbanization; Tourism; Port sector; } \\
\text { Fishermen }\end{array}$ \\
\hline & Provision & $\begin{array}{l}\text { Medicinal resources, raw material } \\
\text { production; limestone, calcareous } \\
\text { rocks and sandstone production } \\
\text { (sediment stock) }\end{array}$ & $\begin{array}{l}\text { Raw materials for pharmacy, } \\
\text { fisheries, and construction }\end{array}$ & $\begin{array}{l}\text { Pharmaceutical, Industry, } \\
\text { Fishermen General and Local } \\
\text { community, }\end{array}$ \\
\hline & Cultural & $\begin{array}{l}\text { Landscape, social relationships, } \\
\text { spiritual values }\end{array}$ & $\begin{array}{l}\text { Education, tourism, recreation, } \\
\text { fisheries activities, identity, } \\
\text { contemplation }\end{array}$ & $\begin{array}{l}\text { General and local community, } \\
\text { NGO's, educational institutions }\end{array}$ \\
\hline
\end{tabular}


Therefore, allow the regulation of human activities by maintaining the ecosystems, their functions and services in a sustainable manner. Furthermore, this understanding helps to support government coastal decision-making policies (Process 6) (Figure 5).

\section{Global Biodiversity Model}

The analysis revealed the negative impact of land-use change over coastal ecosystems of Puerto Morelos. The overall MSA value for mangroves in the reference condition (2005) was on average 0.93 and gradually decreased to $0.81,0.79$, and 0.75 in 2008, 2011 and 2014, respectively. The land conversion contributed to a reduction in MSA in all mangroves areas, representing a loss of $18.6 \%$ in relation to the reference condition. This loss was more intensive in the northern than in the southern area. In 2005, the northern area (area A) had a high MSA, followed by a steep decline in 2008, lowering from high MSA class to relatively high. In the following years, the value remained constant. Area B showed a persistent reduction in the MSA value and went from high to relatively high class. Despite the MSA values decrease observed in areas C and D, they remained in the high class in relation to the reference year (Table 2).

Regarding future projections, vegetation would increase to 0.82 on average in the most optimistic scenario (high MSA class), while it would decrease to 0.42 in the most pessimistic scenario (medium MSA class). In addition, the northernmost area is the one with lower MSA class in both optimistic and pessimistic scenarios, being in relatively high and low classes, respectively. This is followed by area $\mathrm{B}$, that could rise to high MSA class in the best scenario, while it can decrease to relatively low class in the worst scenario. Areas $\mathrm{C}$ and $\mathrm{D}$ would maintain high MSA classes in the best scenarios, while they can decrease to relatively high and medium classes in the worst scenario, respectively (Table 2).

The overall average MSA value of coral reefs remained constant through the years. In the reference condition, the MSA value was 0.82 . There was a slight increase to 0.83 in 2008 , followed by a small decrease to 0.81 in 2011, and then a recovery to 0.83 in 2014 (Table 2).
Specifically, the northernmost area (i.e. Limones) maintained the MSA values constant onto high class throughout the studied period, followed by the southernmost area (i.e. Jardines), also with high MSA class throughout the years. On the other hand, Tanchacte remained with a relatively high MSA class through the years, similar to what was observed in La Bonanza, that showed the lower MSA values.

The constant values of MSA class can also be observed in future projections. On average, coral reefs could maintain MSA classes of 0.83 and 0.81 in the best and worst scenarios, respectively. The area of Limones would be the most constant in biodiversity irrespectively of the scenario, since they will keep with high MSA values in both best and worst projections. The same pattern is observed for Jardines, while Tanchacte and La Bonanza would remain in a relatively high class in both scenarios, with lower values in La Bonanza (Table 2).

\section{DPSIR}

The socio-economic activities such as tourism/recreation, urbanization, fishing, ports and climate change as a driver of socioeconomic impacts, were defined through the literature review performed in the identification of the management sectors section and in consulting the Management Program of Puerto Morelos coral reef National Park (INEGI/INE 2000). The primary local policy related to the study area was considered and addressed as 'drivers' (Table 3) in the analysis. With regard to the Tourism/Recreation driver, the identified pressure was the modification on the health condition of ecosystems. This pressure acts by altering the cover, diversity and complexity of the ecosystems ('state'). As a consequence ('impact'), reduction of ecosystems services and benefits (support, provision, regulation and cultural) occurs. As a 'Response', policing, ecotourism promotion (with appropriate or local guides), educational efforts, monitoring programs, local government actions and policy efforts for integrated management (public and private) are suggested.

Table 2. MSA values for mangroves and coral reefs of different areas obtained through the GLOBIO3 model for the period from 2005 to 2014 . MSA values were classified into five classes that range from high (with higher intactness) to low.

\begin{tabular}{|c|c|c|c|c|c|c|c|}
\hline \multicolumn{6}{|c|}{ a) Mangroves MSA } & \multicolumn{2}{|c|}{ Future scenarios } \\
\hline Site & Area $\left(\mathbf{k m}^{2}\right)$ & 2005 & 2008 & 2011 & 2014 & 2035-B & 2035-W \\
\hline $\mathbf{A}$ & 25 & 0.87 & 0.61 & 0.61 & 0.61 & 0.66 & 0.11 \\
\hline $\mathbf{C}$ & 25 & 0.94 & 0.89 & 0.89 & 0.83 & 0.91 & 0.62 \\
\hline D & 25 & 0.91 & 0.82 & 0.78 & 0.81 & 0.89 & 0.60 \\
\hline Limones & 216.97 & 0.95 & 0.95 & 0.95 & 0.95 & 0.96 & 0.95 \\
\hline La Bonanza & 273.02 & 0.70 & 0.73 & 0.69 & 0.71 & 0.72 & 0.70 \\
\hline Tanchacte & 165.76 & 0.78 & 0.79 & 0.78 & 0.78 & 0.80 & 0.77 \\
\hline Jardines & 75.21 & 0.86 & 0.85 & 0.84 & 0.84 & 0.86 & 0.81 \\
\hline
\end{tabular}

MSA Class

$0.81 \leq$ high $\leq 1 \quad 0.61 \leq$ relatively high $\leq 0.8 \quad 0.41 \leq$ medium $\leq 0.6 \quad 0.21 \leq$ relatively low $\leq 0.4 \quad 0.2 \leq$ low


Framework for management of ecosystem services

Table 3. DPSIR (Drivers-Pressures-State-Impacts-Response) framework for the coastal protection ecosystem services in Puerto Morelos, Mexico.

\begin{tabular}{|c|c|c|c|c|c|}
\hline DRIVERS & PRESSURE & STATE & IMPACTS & RESPONSE & POLICIES \\
\hline $\begin{array}{l}\text { Tourism/ } \\
\text { recreation }\end{array}$ & $\begin{array}{l}\text { Modification on the } \\
\text { ecosystems (health, } \\
\text { pollution) and } \\
\text { integrity }\end{array}$ & $\begin{array}{l}\text { Modification } \\
\text { of the cover, } \\
\text { diversity, } \\
\text { complexity }\end{array}$ & $\begin{array}{l}\text { Reduction of } \\
\text { ecosystems services } \\
\text { and benefits } \\
\text { (support, cultural, } \\
\text { provision and } \\
\text { regulation) }\end{array}$ & $\begin{array}{l}\text { Fiscalization, Ecotourism } \\
\text { promotion (guides), } \\
\text { Educational efforts, } \\
\text { Monitoring programs, Local } \\
\text { government, Policy efforts } \\
\text { for integrated management } \\
\text { (public and private) }\end{array}$ & $\begin{array}{l}\text { Current: Sustainable Tourism } \\
\text { Agenda of Quintana Roo / Puerto } \\
\text { Morelos Reef National Park } \\
\text { Management Program. } \\
\text { Desirable: Sustainable tourism } \\
\text { certification / Marine Spatial } \\
\text { Planning. }\end{array}$ \\
\hline $\begin{array}{l}\text { Fisheries } \\
\text { activities }\end{array}$ & $\begin{array}{l}\text { Modification on } \\
\text { the ecosystems } \\
\text { (health, pollution) } \\
\text { and integrity; } \\
\text { Modification in the } \\
\text { fishery stocks }\end{array}$ & $\begin{array}{l}\text { Modification } \\
\text { of the cover, } \\
\text { diversity, } \\
\text { complexity; } \\
\text { Modification } \\
\text { in the fishery } \\
\text { community }\end{array}$ & $\begin{array}{l}\text { Reduction of } \\
\text { ecosystems services } \\
\text { and benefits } \\
\text { (provision of food, } \\
\text { biomass, support, } \\
\text { biodiversity, cultural } \\
\text { identities, amenities) }\end{array}$ & $\begin{array}{l}\text { Educational efforts, } \\
\text { Fiscalization, Fisheries } \\
\text { policy (fishery } \\
\text { restrictions), Monitoring } \\
\text { programs }\end{array}$ & $\begin{array}{l}\text { Current: Puerto Morelos Reef } \\
\text { National Park Management } \\
\text { Program / National Sustainable } \\
\text { Development Policy for coasts and } \\
\text { oceans, Regulations for the Use and } \\
\text { Exploitation of the Territorial Sea, } \\
\text { Navigable Waterways / General } \\
\text { Law of Ecological Balance and } \\
\text { Environmental Protection. } \\
\text { Desirable: Marine Spatial Planning. }\end{array}$ \\
\hline $\begin{array}{l}\text { Ports and } \\
\text { navigation }\end{array}$ & $\begin{array}{l}\text { Modification on the } \\
\text { ecosystems (health, } \\
\text { pollution) and } \\
\text { integrity }\end{array}$ & $\begin{array}{l}\text { Modification } \\
\text { of the cover, } \\
\text { diversity, } \\
\text { complexity; } \\
\text { Biological } \\
\text { invasions }\end{array}$ & $\begin{array}{l}\text { Reduction of all } \\
\text { ecosystems services } \\
\text { and benefits }\end{array}$ & $\begin{array}{l}\text { Ports regulation, Coastal } \\
\text { management planning (Port } \\
\text { Management), Capacitation } \\
\text { of the port staff }\end{array}$ & $\begin{array}{l}\text { Current: National Sustainable } \\
\text { Development Policy for coasts and } \\
\text { oceans, Regulations for the Use } \\
\text { and Exploitation of the Territorial } \\
\text { Sea, Navigable Waterways / } \\
\text { General Law of Ecological Balance } \\
\text { and Environmental Protection / } \\
\text { Sustainable Tourism Agenda of } \\
\text { Quintana Roo / Puerto Morelos Reef } \\
\text { National Park Management Program. } \\
\text { Desirable: Marine Spatial Planning } \\
\text { / environmental port licensing } \\
\text { based on ecosystem services. }\end{array}$ \\
\hline $\begin{array}{l}\text { Climate } \\
\text { change }\end{array}$ & $\begin{array}{l}\text { Modification on } \\
\text { the ecosystems } \\
\text { (health, pollution, pH } \\
\text { decrease, temperature } \\
\text { increase, diseases) } \\
\text { and integrity }\end{array}$ & $\begin{array}{l}\text { Modification } \\
\text { of the cover, } \\
\text { diversity, } \\
\text { complexity }\end{array}$ & $\begin{array}{l}\text { Reduction of all } \\
\text { ecosystems services } \\
\text { and benefits }\end{array}$ & $\begin{array}{l}\text { Education efforts, Coastal } \\
\text { Management planning, } \\
\text { Government policies for } \\
\text { climate change mitigation }\end{array}$ & $\begin{array}{l}\text { Current: State Programme of Action } \\
\text { on Climate Change Quintana Roo. } \\
\text { Desirable: Local environmental } \\
\text { diagnosis of climate change effects } \\
\text { (Puerto Morelos). }\end{array}$ \\
\hline
\end{tabular}

The Urbanization driver was similar to the Tourism/Recreation driver for the pressure and state categories. However, the reduction of all ecosystem services and benefits were identified as impacts. As a response to this driver we proposed a Coastal Management program with Government participation and educational efforts programs for residents and tourists. For the Fisheries activities driver, the pressure and the state categories were also similar to the Tourism/Recreation and Urbanization drivers. Furthermore, the inclusion of the fish community/stock alteration was included.
Some of the impacts identified for this driver were; the reduction of ecosystem services and benefits like provision of food, biomass, support, biodiversity, cultural identities and amenities. A potential response to this driver could be educational efforts, environmental policing, fisheries policy (fishery restrictions) and monitoring programs. The ports and navigation driver showed a similar pattern regarding the categories of pressure and state, but including also the impact of potential biological invasion by non-native organisms. 
The impacts detected were also the reduction of all ecosystem services and benefits, and the potential responses proposed are a strict ports regulation with a proper coastal management planning (port management) and the capacitation of the port staff. Finally, the last driver identified was Climate Change. Several modifications on the ecosystems affecting their health condition (such as pollution, $\mathrm{pH}$ decrease, temperature increase and diseases, among others) were identified as Climate Change pressures. This driver affects the state causing modification of the coral and mangroves cover, diversity and complexity. The impacts involved include the reduction of all ecosystem services and their benefits. The response proposed are the reinforcement of education and a proper coastal management planning, with the support of Government policies focused on climate change mitigation.

\section{Policy assessment}

The legal framework evaluation allowed the identification of seven policies and tools related to support conservation and sustainable management of marine and coastal areas of Mexico, as well as planning for mitigation and/or avoidance of impacts arising from the ecosystemschange drivers mentioned above. Among these policies (three work on national level, two on state level and two on local level), there are variations on the degree of inclusion of the different agents of change and pressures on coastal areas. (Figure 6).

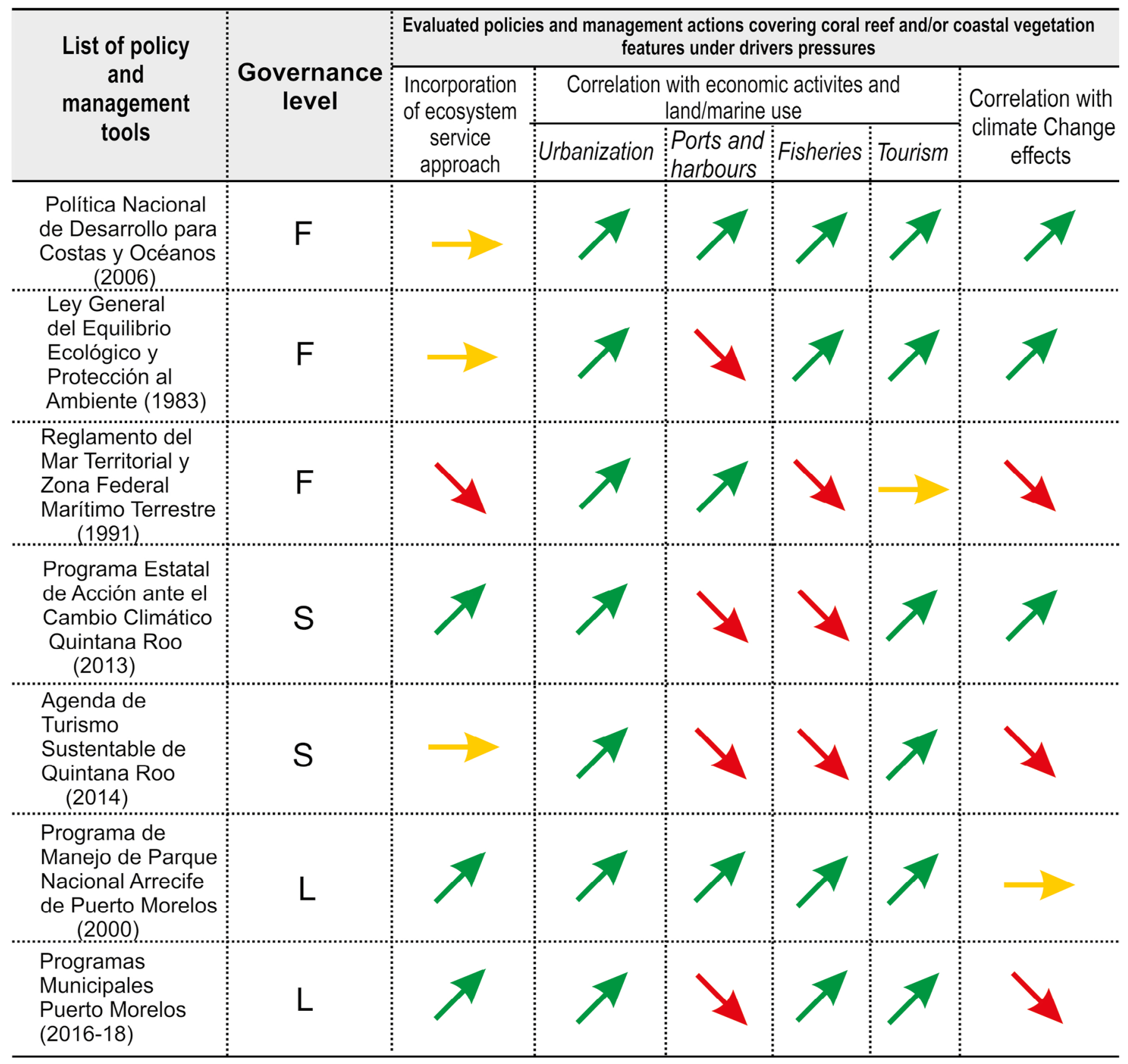

Figure 6. Policy framework assessment. Seven policies and tools applied in Puerto Morelos. F corresponds to Federal level, S to State level and L to local, Puerto Morelos level. Green arrows correspond to presence/application, yellow arrows correspond to mentioned but partially attended, and red arrows correspond to absence/not attended. 
In all the policies, urbanization and tourism activity processes were identified as drivers associated with land use and coastal changes. Comparing the seven policies analysed, only three of them have integrated in their guidelines ecosystem services. Three others mentioned management efforts but do not explicitly discuss ecosystem services while the last one did not mention any ecosystem services. The ports, navigation and fisheries drivers were included in marine related policies exclusively, although it could be directly associated with climate change agenda and conservation laws. The effects of climate change were addressed in three policies and laws of the management framework. The "Programa de Manejo Parque Nacional Arrecife de Puerto Morelos" (Puerto Morelos Reef National Park Management Program) and "Política Nacional de Desarrollo Sostenible para costas y océanos" (National Sustainable Development Policy for coasts and oceans) policies were broader for considering most of the analyzed drivers.

\section{Discussion}

This study resulted in a low cost and easily applicable workflow to generate an Ecosystem-Based Management (EBM) framework for coastal ecosystems. This approach allowed us to identify the main ecosystem services, their current state and their pressures. Our case study from the Caribbean mangrove and coral reef ecosystems (Puerto Morelos, Mexico) is an explicit example of how recent socio-economic pressures are altering coastal ecosystems. This workflow was first developed using an 'ecosystem information base' that systematizes relevant information about the studied ecosystems. It later analyzes the current policies and their effectiveness. To construct the information base, we used different strategies, such as analysing the ecosystems as "Management Units" which revealed a high complexity of socioeconomic activities depending on these ecosystems. Also, we used an ecosystem services matrix (ESM), that assisted in the characterization and identification of ecosystem services of the study area (Geange et al. 2019). According to Jacobs et al (2015), matrix approaches have weaknesses such as inferior methodological transparency, uncertainties with regard to the quality of the results, low replicability and lack of reliability. The use of ESM to complement other methodologies becomes important to reinforce additional assumptions about future potential provision of ecosystem services (IPCC 2001). Given the above, we constructed a Conceptual Model to understand the interplay coastal processes, and then modelled past biodiversity loss and predictions of future scenarios in both mangroves and coral reefs ecosystems using the GLOBIO3 model. Finally, we evaluated the governance section in the DPSIR framework and Policy Assessment.

The conceptual model pointed to two main pieces of information: the framework steps (methodology) and the processes occurring in coastal ecosystems (results). It was helpful by connecting the different processes that occur in these coastal systems (biological and social interactions), which facilitates the understanding of how each process can be evaluated. As a result, it decoupled the several 'pieces' of the systems allowing identification of the gaps where management action is needed. This work indicated that services provided by mangrove and coral reef ecosystems (i.e. climate regulation, food supply, landscape, among others) simultaneously are basis and support for the socio-economic activities of the region. Indeed, these systems not only protect biodiversity but also the coastal land, essential for human development (Douvere 2008).
It is important to note that the conceptual model adopted simplifies a complex set of human activities and marine ecosystem services. Additionally, it does not map other products, such as social benefits and tax payments. Among the ecosystem services provided by both ecosystems, only 'coastal protection' was evaluated due to its importance for the development of socio-economic activities on coastal land and sea. Mangroves reduce the water flow speed and the roots hold sediments, increasing the coastline, while coral reefs dissipate the energy of waves, decreasing the energy flow to the land and reducing coastal erosion (Spalding et al. 2014), providing coastal protection.

The GLOBIO3 model clearly showed pressures on mangrove systems, leading to biodiversity loss from 2005 to 2014. Among the activities affecting the mangrove cover in Puerto Morelos, land conversion by tourism and urbanization was considered the major one prompted by the construction of hotels, resorts, and houses, affecting coastal protection (Rodríguez-Martínez 2008, Costanza et al. 2014, Spalding et al. 2014). Despite this reduction in mangrove area, the studied areas still maintained a considerable mangrove cover. Similarly, a previous study conducted in the same area, showed about $27 \%$ of mangrove loss from 1981 to 2005, but just 1\% from 2005 to 2010 (Vázquez-Lule et al. 2009). This relatively low suppression of mangroves could be due to the increase of public policies in recent years and sustainable land use land cover (LULC) strategies (see Figure 6 for an overview of policies). However, the socio-economic pressures are expected to keep increasing in Puerto Morelos region, and, if it continues leading to mangrove suppression at the same pace over the next two decades (our worst scenario), the ecosystem services provision will be threatened (Koch et al. 2009, Duke et al. 2007, Taylor et al. 2018). A better path to take for the next 20 years would be our best scenario, in which communities and government work together to develop strategies and policies to low cost and feasible mangrove restoration, in order to better cope with land-use change (Dale et al. 2014).

In contrast to mangroves, the coral reef biodiversity loss indexes kept constant during the last decade (see also Banaszek \& Álvarez-Filip, 2014, Álvarez-Filip \& Banaszek, 2016) and will remain the same in the next 20 years to our both pessimistic and optimistic scenarios. It seems likely that the recent reduction of coral degradation might be a result of conservation actions and novel policies, especially regarding the Puerto Morelos Coral Reef National Park management plan. However, the good state of the corals revealed by GLOBIO3 could also be due to analytical issues. That is, because there is no reliable model programs for marine environments and our GLOBIO3 adaptation used high resilience indexes that generated higher MSA values, overestimating the overall coral quality from some areas, such as La Bonanza (Ladd \& Collado-Vides, 2013, Álvarez-Filip \& Banaszek, 2016). Moreover, it is possible that other drivers not considered in the projections (e.g. the increase in sewage, climate change, diseases, ocean acidification), could affect the health of coral organisms and their distribution in the future (Fine \& Tchernov 2007, Sutherland et al. 2010, Hughes et al. 2017). The mangrove and coral reef cover projections demonstrate that the efforts must continue to maintain the conservation of these ecosystems. Therefore, the cumulative impacts on both ecosystems require the attention of stakeholders (e.g. governmental institutions, environmental managers, civil society, among others) to remain updated and to develop new policy-oriented governance from scientific-based analysis with the support of different stakeholders, in order to improve the ocean health and the quality of coastal ecosystems. 
The DPSIR framework (identification of the management sectors) complements the ecosystem modeling section by revealing that the main drivers to both coastal ecosystems are linked to the urbanization processes (tourism/recreation, urbanization, fisheries activities, ports and navigation). Even when compared to the economic and social benefits derived from such activities, human activities are affecting the quality of life of surrounding residents and visitors, since pressures produce changes in the state of ecosystems and the impacts they generate over ecosystem services are directly related to the quality of the environment. The responses identified to these drivers constitute suggestions for sustainable development in order to maintain the provision of ecosystem services. Tallis et al. (2010) highlight the need to structure applicable and balanced governance agendas to address the complex issues associated with coastal systems. Multi-specific planning and management proposals can help to better understand and address this challenge.

The survey of policies was the final step (identification of the management sectors) to create a legal framework that would precede governance actions. This was particularly complex as (1) policies work on different levels of governance, (2) information is usually dispersed, and (3) most policies are focused on sectoral activities instead of an integrated perspective. At the federal level, Sustainable Coastal and Marine Management Policy (SEMARNAT 2006) is the only instrument that functions as an integrative policy. That is, several other instruments and laws emphasized specific drivers and failed to correlate the synergistic impacts on the environment (especially considering the climate change effects). The state management framework functions by considering the main drivers, threats and natural features of its coastal zone. It also develops guidelines and programs indicating the actions that shall be accomplished. At the regional scale (Quintana Roo state) policies contemplate two of the main drivers of pressure in coastal ecosystems: climate change and tourism, which are related with urbanization. Another important effort identified, but not included in the Mexican legal framework, is the "Good Practices for Climate Change Adaptation project, Mexico, Quintana Roo State" (Silva et al. 2019, UN 2019). This effort has a focus on the management of land conversion, which is the current main driver of changes (directly or indirectly) over mangrove and coral reef ecosystems. Finally, a federal environmental tool applied on a local scale has been directing its efforts for conservation of Puerto Morelos coral reefs through the delimitation of the Coral Reef National Park and its management plan (Carabias-Lillo 2000).

The integration of ecosystem services knowledge into these policies is a valuable approach to incorporate the relationship between values and benefits delivered by the ecosystems and the different social activities (Santos-Martín et al. 2015). Indeed, there are some examples of successful coastal management practices that incorporated ecosystem services in their decisions (Luisetti et al. 2011, Guerry et al. 2012, Kelble et al. 2013). For example, in Belize, the Integrated Coastal Zone Management Plan allows the continuous use of the ocean, such as coastal development and aquaculture, but in high risk areas, the natural habitats reduction is limited up to $20 \%$ (Arkema et al. 2014). In addition, there should be incentives to update and adapt current policies to be able deal with potential new sources of and increases in drivers of pressure in the next years, given that the population growth in Puerto Morelos is not being addressed adequately by these policies. This lack of attention to population growth may result in the intensification of pressures on the ecosystems (Hernández-Terrones et al. 2011).
It follows that an integrated coastal management must be linked with public policies for sustainable development of people and spaces (socioecological systems) with the participation of different stakeholders (Muñoz 2020). The Puerto Morelos Coral Reef National Park has a great potential of awareness and knowledge from the population about the importance of reef ecosystems for the society. An environmental licensing based on ecosystem services (for ports, urbanization and tourism facilities) added to a local Land Use Master Plan and an international sustainable tourism certification is recommended. Finally, a Marine Spatial Planning (MSP) may contribute to harmonizing those activities who depend on, use and disturb the marine and coastal environment (Ehler \& Douvere 2009, Collie et al. 2013).

Although the present study contributes to the advancement of approaches based on marine ecosystems, it also identified some caveats and limitations that require improvement. For instance, some processes that also occur in the coastal zone were not considered by the conceptual model and the scenario projections. The decision to omit these processes was taken owing to the amount of information required to incorporate many processes, as well as reducing the complexity of the models and making them more understandable. Focusing on only one service (coastal protection) and its main driver (urbanization) made possible a well-grounded understanding about the overall problem and development of solutions to the principal issues of mangroves and coral reef losses in the region. Moreover, despite the fact that GLOBIO3 models have been developed for terrestrial systems (Alkemade et al. 2009), in this study we were able to adapt land-use change to coral reef's cover. These promising approaches require support from scientific communities to develop a suitable solution applicable to marine environments so as to avoid model biases. Although improvements should be made to create a more reliable model and future predictions for these systems, the adaptations applied in this study were worthwhile and provided us with a broader view of the issue. Despite these limitations in some specific parts of our EBM framework, the complementary pathway used in this study leads us to have a general understanding for strengthening decision-makers/policy formulation and implementation which will assist in ensuring sustainable development and maintenance of ecosystem services in coastal regions. It is worth noting that through a collaborative process, which involved several researchers with different backgrounds, it was possible to create this framework as a more comprehensive and complete tool. Given the global trends in biodiversity loss due to anthropogenic impacts (IPBES 2019), and the increasing pressure of climate change on ecosystems (IPCC 2014), the development of new models to ascertain the health and sustainability of coastal ecosystems has increased relevance, especially those that include the use of policies which take into account different areas of knowledge and cultural backgrounds. Therefore, this type of collaborative approach is essential to face the challenges that arise in the Anthropocene era (Berkes 2017).

Overall, this report revealed relationships between ecosystems with other elements such as services and beneficiaries, as well as human and natural drivers. The proposed strategy ties key scientific information necessary to understand the functioning of the ecosystems involved. The conceptual model evidenced the ecosystems interplay through main components and processes. The empirical model assessed the quantitative effects of coastal and marine activities and land-use change on the ecosystems. 
Seven potential policies and tools from three different governance levels can be potentially used in an integrated ecosystem approach. We highlight possible shortcomings in current laws, which should be considered when expanding the formulation and implementation of public policies toward environmental governance good practices. The future of the ocean depends on successful immediate implementation of a comprehensive governance framework that moves away from a sectoral management approach to an integrated one (Foley et al. 2010). Marine ecosystems are still poorly studied concerning their ecosystem services. It is, therefore, relevant to understand all the range of services provided by these systems and evaluate (and value) the costs of degrading and losing them (Spalding et al. 2014). Mangrove and coral reef ecosystems in Puerto Morelos were used as an example to demonstrate how it is possible to design and develop a workflow with integrated disciplines information for the development of an EBM. We suggest that stakeholders (e.g. all governmental institutions, second sector and the local society) propose viable science-based solutions to improve the marine ecosystem health through EBM underpinning the source of ecosystem services benefits for the local communities and the whole social system.

\section{Acknowledgments}

Authors would like to thank the organizing committee and professors from the São Paulo School of Advanced Science on Scenarios and Modeling in Biodiversity and Ecosystem Services for Human Well-Being (SPSAS Scenarios), promoted by Fundação de Amparo à Pesquisa do Estado de São Paulo (FAPESP), convened on July of 2019 in Hotel Fonte Colina Verde, in the city of Sao Pedro, Brazil. All the members of this paper received financial support to attend the course from SPSAS Scenarios/ FAPESP, with the exception of F. H. C. Sanches, that received financial support from his postdoctoral grant (Process FAPESP number 2017/17337-9), and E. Casagranda that received travel financial support from CONICET Grant, PICT 2016-2173 FONCYT. B. Possamai appreciates the financial support provided by Conselho Nacional de Desenvolvimento Científico e Tecnológico (CNPq 146958/2015-2) as well. This study was financed in part by the Coordenação de Aperfeiçoamento de Pessoal de Nível Superior - Brasil (CAPES) - 88882.438098/201901 to J. Correa da Costa, 88882.181088/2018-01 to N. S. Zamboni, and 88882.316096/2019-01 to L. Faroni-Perez. The authors declare no conflict of interest related to the publication of this manuscript. Moreover, we thank Professor Milton Asmus for his relevant contribution, guidance and review of the final conceptual model.

\section{Author Contributions}

Andrés Sánchez-Quinto: Substantial contribution in the concept and design of the study, Contribution to data collection, Contribution to data analysis and interpretation, Contribution to manuscript preparation, Contribution to critical revision, adding intellectual content.

Julliet Correa da Costa: Substantial contribution in the concept and design of the study, Contribution to data collection, Contribution to data analysis and interpretation, Contribution to manuscript preparation, Contribution to critical revision, adding intellectual content.
Nadia S. Zamboni: Substantial contribution in the concept and design of the study, Contribution to data collection, Contribution to data analysis and interpretation, Contribution to manuscript preparation, Contribution to critical revision, adding intellectual content.

Fábio H. C. Sanches: Substantial contribution in the concept and design of the study, Contribution to data collection, Contribution to data analysis and interpretation, Contribution to manuscript preparation, Contribution to critical revision, adding intellectual content.

Silas C. Principe: Substantial contribution in the concept and design of the study, Contribution to data collection, Contribution to data analysis and interpretation, Contribution to manuscript preparation, Contribution to critical revision, adding intellectual content.

Evangelina V. Viotto: Substantial contribution in the concept and design of the study, Contribution to data collection, Contribution to data analysis and interpretation, Contribution to manuscript preparation, Contribution to critical revision, adding intellectual content.

Elvira Casagranda: Substantial contribution in the concept and design of the study, Contribution to data collection, Contribution to data analysis and interpretation, Contribution to manuscript preparation, Contribution to critical revision, adding intellectual content.

Francisco A. da Veiga Lima: Substantial contribution in the concept and design of the study, Contribution to data collection, Contribution to data analysis and interpretation, Contribution to manuscript preparation, Contribution to critical revision, adding intellectual content.

Bianca Possamai: Substantial contribution in the concept and design of the study, Contribution to data collection, Contribution to data analysis and interpretation, Contribution to manuscript preparation, Contribution to critical revision, adding intellectual content.

Larisse Faroni-Perez: Substantial contribution in the concept and design of the study, Contribution to data collection, Contribution to data analysis and interpretation, Contribution to manuscript preparation, Contribution to critical revision, adding intellectual content.

\section{Conflicts of Interest}

The authors declare that they have no conflict of interest related to the publication of this manuscript.

\section{References}

AGUILAR, V., KOLB, M., HERNÁNDEZ, D., URQUIZA, T. \& KOLEFF P. 2008. Prioridades de Conservación de la Biodiversidad Marina de México. CONABIO. Biodiversitas, 79:1-15.

ALKEMADE, R., VAN OORSCHOT, M., MILES, L., NELLEMANN, C., BAKKENES, M., \& TEN BRINK, B. 2009. GLOBIO3: a framework to investigate options for reducing global terrestrial biodiversity loss. Ecosystems, 12(3): 374-390.

ALONGI, D.M. 2009. Paradigm shifts in mangrove biology. Coastal Wetlands an Integrated Ecosystem Approach. Elsevier. Amsterdam. p. 615-640.

ÁLVAREZ-FILIP, L. \& BANASZAK, A.T. 2016. Informe de Programa de Conservación de Especies en Riesgo (PROCER). Parque Nacional Arrecife de Puerto Morelos, Puerto Morelos.

ARKEMA, K.K., VERUTES, G.M., BERNHARD, J.R., CLARKE, C., ROSADO, S., CANTO, M., WOOD, S.A., RUCKELSHAUS, M., ROSENTHAL, A., MCFIELD, M. 2014. Assessing habitat risk from human activities to inform coastal and marine spatial planning: a demonstration in Belize. Environ. Res. Lett. 9, 11, http://dx.doi.org/10.1088/17489326/9/11/114016. 
ARKEMA, K.K., VERUTES, G.M., WOOD, S.A., CLARKE-SAMUELS, C., ROSADO, S., CANTO, M., ROSENTHAL, A., RUCKELSHAUS, A., GUANNEL, G., TOFT, J., FARIES, J., SILVER, J.M., GRIFFIN, R. \& GUERRY,A.D. 2015. Embedding ecosystem services in coastal planning leads to better outcomes for people and nature. P. Natl. Acad. Sci. 112(24): 7390-7395.

ASMUS, M.L., NICOLODI, J., SCHERER, M.E.G., GIANUCA, K., COSTA, J.C., GOERSCH, L., HALLAL, G., VICTOR, K.D., FERREIRA, W.L., JÚLIA, N.D.A. \& ROSA PEREIRA, C. 2018. Simples para ser útil: base ecossistêmica para o gerenciamento costeiro. Desenvolvimento e Meio Ambiente. 44.

BANASZAK, A.T. \& ÁLVAREZ-FILIP, L. 2014. Diagnostico y estado de conservación de las poblaciones de Acropora en el Parque Nacional Arrecife de Puerto Morelos. Unidad Académica de Sistemas Arrecifales, ICML, UNAM. $57 \mathrm{p}$.

BARBIER, E.B. 2016. The protective service of mangrove ecosystems: A review of valuation methods. Mar. Pollut. Bull. 109(2): 676-681.

BARBIER, E.B., KOCH, E.W., SILLIMAN, B.R., HACKER, S.D., WOLANSKI, E., PRIMAVERA, J. \& STOMS, D.M. 2008. Coastal ecosystem-based management with nonlinear ecological functions and values. Science. 319(5861): 321-323.

BERKES, F. (2017). Environmental Governance for the Anthropocene? SocialEcological Systems, Resilience, and Collaborative Learning. Sustainability, 9(7), 1232. https://doi.org/10.3390/su9071232

BROWN, G. 2006. Mapping landscape values and development preferences: a method for tourism and residential development planning. Int. J. Tour. Res. 8(2): 101-113.

CARABIAS-LILLO, J. 2000. Programa de manejo Parque Nacional Arrecife de Puerto Morelos: México.

COLLIE, J. S.; (Vic) ADAMOWICZ, W. L.; BECK, M. W.; CRAIG, B.; ESSINGTON, T. E.; FLUHARTY, D.; RICE, J.; SANCHIRICO, J. M. 2013. Marine spatial planning in practice. Estuarine and Coastal Shelf Science, 117, 1-11, 2013. doi: 10.1016/j. ecss.2012.11.010

COMUNICACIÓN SOCIAL DE PUERTO MORELOS. 2019. https:// puertomorelos.gob.mx/comunicacionsocial/boletines/puerto-morelos-ytodos-sus-atractivos-listos-para-recibir-a-miles-de-vacacionistas/ (last accessed on 26/02/2020)

CONABIO. 2006. Minuta de la Reunión interinstitucional para la definición de manglar. CONABIO, INE, Conafor, Conagua, Inegi-Aguascalientes. Available on: http://www.biodiversidad.gob.mx/ecosistemas/manglares2013/ pdf/minuta_tipos_de_manglar.pdf

CONABIO-CONANP-TNC-PRONATURA. 2007. Vacíos y omisiones en conservación de la biodiversidad marina de México:océanos, costas e islas. Comisión Nacional para el Conocimiento y Uso de la Biodiversidad, Comisión Nacional de Aéreas Naturales Protegidas. The Nature Conservancy - Programa México, Pronatura. Mexico.

CORONADO, C., CANDELA, J., IGLESIAS-PRIETO, R., SHEINBAUM, J., LÓPEZ, M. \& OCAMPO-TORRES, F.J. 2007. On the circulation in the Puerto Morelos fringing reef lagoon. Coral Reefs. 26(1):149-63.

COSTANZA, R., GROOT, R., SUTTON, P., VAN DER PLOEG, S., ANDERSON, S.J., KUBISZEWSKI, I., FARBER, F. \& TURNER, R.K. 2014. Changes in the global value of ecosystem services. Global Environ. Chang. 26: 152-158.

DALE, P.E.R., KNIGHT, J.M. \& DWYER, P.G. 2014. Mangrove rehabilitation: a review focusing on ecological and institutional issues. Wetlands Ecol Manage 22, 587-604.

DASÍ, J.F. 2011. Territorialidad y buen gobierno para el desarrollo sostenible: nuevos principios y nuevas políticas en el espacio europeo. Universitat de València.

DÍAZ, S., PASCUAL, U., STENSEKE, M., MARTÍN-LÓPEZ, M., WATSON, R.T., MOLNÁR, Z., HILL, R., CHAN, K.M.A., BASTE, I.A., BRAUMAN, K.A., POLASKY, S., CHURCH, A., LONSDALE, M., LARIGAUDERIE, A., LEADLEY, P.W., VAN OUDENHOVEN, A.P.E., VAN DER PLAAT, F., SCHRÖTER, M., LAVOREL, S., AUMEERUDDY-THOMAS, Y., BUKVAREVA, E., DAVIES, K., DEMISSEW, S., ERPUL, G., FAILLER, P., GUERRA, C.A., HEWITT, C.L., KEUNE, H., LINDLEY, S. \& SHIRAYAMA, Y. 2018. Assessing nature's contributions to people. Science. 359(6373): 270-272.
DOUVERE, F. 2008. The importance of marine spatial planning in advancing ecosystem-based sea use management. Mar. Policy. 32(5): 762-771.

DUBINSKY, Z. \& FALKOWSKI, P. 2011. Light as a source of information and energy in zooxanthellate corals. In Coral reefs: an ecosystem in transition. Springer, Dordrecht. 107-118.

DUKE, N.C., MEYNECKE, J.O., DITTMANN, S., ELLISON, A.M., ANGER, K., BERGER, U. \& KOEDAM, N. 2007. A world without mangroves? Science, 317(5834): 41-42.

EHLER, C.; DOUVERE, F.2009. Marine spatial planning: A step-by-step approach toward Ecosystem-based Management. IOC Manual. Paris: Programme, Intergovernmental Oceanographic Commission and Man and the Biosphere - UNESCO.

FAO - Food and Agriculture Organization of the United Nations. 2008. Loss of mangroves alarming. FAONewsroom. Available on: http://www.fao.org/ newsroom/en/news/2008/1000776/index.

FELLER I.C., FRIESS, D.A., KRAUSS, K.W. \& LEWIS III, R.R. 2017. The state of the world's mangroves in the $21^{\text {st }}$ century under climate change. Hydrobiologia 803: 1-12.

FINE, M. \& TCHERNOV, D. 2007. Scleractinian coral species survive and recover from decalcification. Science. 315(5820): 1811-1811.

FOLEY, M.M., HALPERN, B.S., MICHELI, F., ARMSBY, M.H., CALDWELL, M.R., CRAIN, C.M. \& CARR, M.H. 2010. Guiding ecological principles for marine spatial planning. Mar. Policy. 34(5): 955-966.

GARI, S.R., NEWTON, A. \& ICELY, J.D. 2015. A review of the application and evolution of the DPSIR framework with an emphasis on coastal socialecological systems. Ocean Coast. Manage. 103: 63-77.

GEANGE, S., TOWNSEND, M., CLARK, D., ELLIS, J. I., \& LOHRER, A. M. (2019). Communicating the value of marine conservation using an ecosystem service matrix approach. Ecosystem services, 35, 150-163.

GIRI, C., OCHIENG, E., TIESZEN, L.L., ZHU, Z., SINGH, A., LOVELAND, T. \& DUKE, N. 2011. Status and distribution of mangrove forests of the world using earth observation satellite data. Global Ecol. Biogeogr. 20(1): 154-159.

GÓMEZ, E.P.C. 2020. Municipios turísticos en Quintana Roo: origen y problemáticas. Turismo y Sociedad, 26, 89-110.doi:https://doi. org/10.18601/01207555.n26.04

GRANEK, E.F., POLASKY, S., KAPPEL, C.V., REED, D.J., STOMS, D.M., KOCH, E.W., KENNEDY, C.J., CRAMER, L.A., HACKER, S.D., BARBIER, E.B., ASWANI, S., RUCKELSHAUS, M., PERILLO, G.M.E., SILLIMAN, B.R., MUTHIGA, N., BAEL, D. \& WOLANSKI, E. 2010, Servicios de ecosistemas como lenguaje común para la gestión basada en ecosistemas costeros. Conservation Biology, 24(1): 207-216. doi: 10.1111 / j.1523-1739.2009.01355.x

GUANNEL, G., ARKEMA, K., RUGGIERO, P. \& VERUTES, G. 2016. The power of three: coral reefs, seagrasses and mangroves protect coastal regions and increase their resilience. PloS One, 11(7): e0158094.

GUERRY, A.D., RUCKELSHAUS, M.H., ARKEMA, K.K., BERNHARDT, J.R., GUANNEL, G., KIM, C. K., Marsik, M., PAPENFUS, M., TOFT, J.E., VERUTES,G., WOOD, S.A., BECK, M., CHAN, F., MA CHAN, K., GELFENBAUM, G., GOLD, B.D., HALPERN, B.S., LABIOSA, W.B., LESTER, S.E., LEVIN, P.S., MCFIELD, M., PINSKY, M.L., PLUMMER, M., POLASKY, S., RUGGIERO, P., SUTHERLAND, D.A., TALLIS, H., DAY A. \& SPENCER J. 2012. Modeling benefits from nature: using ecosystem services to inform coastal and marine spatial planning, International Journal of Biodiversity Science, Ecosystem Services \& Management, 8(1-2): 107-121. DOI: 10.1080/21513732.2011.647835

HALPERN, B. S., WALBRIDGE, S., SELKOE, K. A., KAPPEL, C. V., MICHELI, F., D’AGROSA, C., BRUNO, J.F. CASEY, K.S., EBERT C., FOX, H.E., FUJITA, R., HEINEMANN, D., LENIHAN , H.S., MADIN, E.M.P., PERRY, M.T., SELIG, E.R., SPALDING, M., ATENECK, R. \& WATRSON, R. 2008. A global map of human impact on marine ecosystems. Science, 319(5865), 948-952. DOI: 10.1126/science.1149345

HERNÁNDEZ-TERRONES, L., REBOLLEDO-VIEYRA, M., MERINOIBARRA, M., SOTO, M., LE-COSSEC, A. \& MONROY-RÍOS, E. 2011. Groundwater pollution in a karstic region (NE Yucatan): baseline nutrient content and flux to coastal ecosystems. Water, Air, \& Soil Pollution. 218(1-4): 517-528. 
HOEGH-GULDBERG, O., HUGHES, L., MCINTYRE, S., LINDENMAYER, D.B., PARMESAN, C., POSSINGHAM, H.P. \& THOMAS, C.D. 2008. Assisted colonization and rapid climate change. Science. 321(5887): 345-346.

HUGHES, T. P., KERRY, J. T., ÁlVAREZ-NORIEGA, M., ÁlVAREZROMERO, J. G., ANDERSON, K. D., BAIRD, A. H.,BABCOCK, R.C., BEGER, M., BELLWOOD, D.R., BERKELMANS, R., BRIDGE, T.C., BUTLER, I.R., BYRNE, M., CANTIN, N.E., COMEAU, S., CONNOLLY, S.R., CUMMING, G.S., DALTON, S.J., DIAZ-PULIDO, G., EAKIN, C.M., FIGUEIRA, W.F., GILMOUR, J.P., HARRISON, H.B., HERON, S.F., HOEY, A.S., HOBBS, J.P.A.,HOOGENBOOM, M.O., KENNEDY, E.V., KUO, C.,LOUGH, J.M., LOWE, R.J., LIU, G. MCCULLOCH, M.T., MALCOLM, H.A., MCWILLIAM, M.J., PANDOLFI, J.M., PEARS, R.J., PRATCHETT, M.S., SCHOEPF, V., SIMPSON, T., SKIRVING, W.J., SOMMER, B., TORDA, G., WACHENFELD, D.R., WILLIS, B.L. \& SHAUN W.K. 2017. Global warming and recurrent mass bleaching of corals. Nature, 543(7645), 373-377.

INAFED - Instituto Nacional para el Federalismo y el Desarrollo Municipal en coordinación con los Gobiernos de los Estados. 2019. (last access in $15 / 09 / 2019)$

INEGI - Conteo General de Población y Vivienda. 2010. Resultados definitivos, tabulados básicos, México.

INEGI/INEO-INSTITUTO NACIONAL DE ESTADÍSTICA, GEOGRAFÍA E INFORMÁTICA/ INSTITUTO NACIONAL DE ECOLOGÍA. 2000. Indicadores de desarrollo sustentable en México. Mexico.

IPBES - Intergovernmental Science-Policy Platform on Biodiversity and Ecosystem Services. 2019. Global assessment report on biodiversity and ecosystem services of the Intergovernmental Science-Policy Platform on Biodiversity and Ecosystem Services.

IPCC-INTERGOVERNMENTAL PANEL ON CLIMATE CHANGE. 2001: Impacts, Adaptation, and Vulnerability. Contribution of Working Group II to the Third Assessment Report of the Intergovernmental Panel on Climate Change; Cambridge University Press: Cambridge, UK, 20

IPCC-INTERGOVERNMENTAL PANEL ON CLIMATE CHANGE. 2014 Climate change 2014: synthesis report. Contribution of Working Groups I. II and III to the Fifth Assessment Report of the intergovernmental panel on Climate Change. IPCC, Geneva, Switzerland. 151p.

IUCN - International Union for Conservation of Nature. 2018. The IUCN Red List of Threatned Species. Disponível em: https://www.iucnredlist.org/. Acesso: Fevereiro de 2019

JACOBS, S.; BURKHARD, B.; VAN DAELE, T.; STAES, J.; SCHNEIDERS, A. 2015. The Matrix Reloaded: A review of expert knowledge use for mapping ecosystem services. Ecol. Model.295, 21-30. DOI: 10.1016 / j.ecolmodel.2014.08.024.

JANSE, J.H., KUIPER, J.J., WEIJTERS, M.J., WESTERBEEK, E.P., JEUKEN, M.H.J.L., BAKKENES, M.,ALKEMADE, R., MOOIJ, W.M. \& VERHOEVEN, J.T.A. 2015. GLOBIO-Aquatic, a global model of human impact on the biodiversity of inland aquatic ecosystems. Environ. Sci. Policy. 48: 99-114.

JORDÁN-DAHLGREN, E. \& RODRÍGUEZ-MARTÍNEZ R.E. 1998. Posthurricane initial recovery of Acropora palmata in two reefs of the Yucatan Peninsula, Mexico. B. Mar. Sci. 63(1): 213-228.

JORDÁN-DAHLGREN, E. 1979. Estructura y composición de arrecifes coralinos en la región noreste de la Península de Yucatán, México. Anales del Instituto de Ciencias del Mar y Limnología, Universidad Nacional Autónoma de México 6: 69-86.

KELBLE, C.R., LOOMIS, D.K., LOVELACE, S., NUTTLE, W.K., ORTNER, P.B., FLETCHER, P., COOK, G.S., LORENZ, J.J. \& BOYER, J.N. 2013. The EBM-DPSER conceptual model: integrating ecosystem services into the DPSIR framework, PLoS One. 8(8): e70766.

KOCH, E.W., BARBIER, E.B., SILLIMAN, B.R., REED, D.J., PERILLO, G.M., HACKER, S.D. \& HALPERN, B.S. 2009. Non-linearity in ecosystem services: temporal and spatial variability in coastal protection. Front. Ecol. Environ. 7(1): 29-37.

KRUEGER, T., PAGE, T., HUBACEK, K, SMITH, L \& HISCOCK, K. 2012. The role of expert opinion in environmental modelling. Environ. Modell. Softw. 36: 4-18.
LADD, M.C. \& COLLADO-VIDES, L. 2013. Practical applications of monitoring results to improve managing for coral reef resilience: a case study in the Mexican Caribbean. Biodivers. Conserv. 22(8): 1591-1608.

LESSER, M.P., SLATTERY, M. \& MOBLEY, C.D. 2018. Biodiversity and functional ecology of mesophotic coral reefs. Annu. Rev. Ecol. Evol. S. 49: 49-71.

LIQUETE, C., PIRODDI, C., DRAKOU, E.G., GURNEY, L., KATSANEVAKIS, S., CHAREF, A. \& EGOH, B. 2013. Current status and future prospects for the assessment of marine and coastal ecosystem services: a systematic review. PloS One. 8(7): e67737.

LUISETTI, T., TURNER, R. K., BATEMAN, I. J., MORSE-JONES, S., ADAMS, C., \& FONSECA, L. 2011. Coastal and marine ecosystem services valuation for policy and management: Managed realignment case studies in England. Ocean \& Coastal Management, 54(3), 212-224. doi:10.1016/j. ocecoaman.2010.11.003

MARTIN, T.G., BURGMAN, M.A., FIDLER, F., KUHNERT, P.M., LOWCHOY, S., MCBRIDE, M. \& MENGERSEN, K. 2012. Eliciting expert knowledge in conservation science. Conserv. Biol. 26(1): 29-38.

MAYNARD, J.A., ANTHONY, K.R.N., HARVELL, C.D., BURGMAN, M.A., BEEDEN, R., SWEATMAN, H. \& WILLIS, B.L. 2011. Predicting outbreaks of a climate-driven coral disease in the Great Barrier Reef. Coral Reefs. 30(2): 485-495.

MCCLANAHAN, T., ALLISON, E.H. \& CINNER, J.E. 2015. Managing fisheries for human and food security. Fish Fish. 16(1): 78-103.

MCLEOD, K.L. \& LESLIE, H.M. 2009. Why ecosystem-based management. In Ecosystem-based management for the oceans. 3-12.

MEA -. Millenium Ecosystem Assessment. 2003. Ecosystem and human wellbeing: A framework for assessment. Island Press, Washington.

MEA - Millenium Ecosystem Assessment. 2005. Ecosystems and human wellbeing. (v.5) Island Press, Washington.

MILOSLAVICH, P., DÍAZ, J.M., KLEIN, E., ALVARADO, J.J., DÍAZ, C., GOBIN, J. \& BASTIDAS, A.C. 2010. Marine biodiversity in the Caribbean regional estimates and distribution patterns. PloS one. 5(8): e11916.

MOBERG, F. \& FOLKE, C. 1999. Ecological goods and services of coral reef ecosystems. Ecol. Econ. 29(2): 215-233.

MUÑOZ, JM.B. 2020. Progress of coastal management in Latin America and the Caribbean. Ocean \& Coastal Management, 184, 105009.

NORDLUND, L.M., KOCH, E.W., BARBIER, E.B. \& CREED, J.C. 2016. Seagrass ecosystem services and their variability across genera and geographical regions. PLoS One. 11(10): e0163091.

PATRÍCIO, J., ELLIOTT, M., MAZIK, K., PAPADOPOULOU, K.N. \& SMITH, C.J. 2016. DPSIR - Two decades of trying to develop a unifying framework for marine environmental management? Frontiers in Marine Science. (v.3). 177p.

PELAGE L., DOMALAIN, G., LIRA, A.S., TRAVASSOS P. \& FRÉDOU, T. 2018. Coastal Land Use in Northeast Brazil: Mangrove Coverage Evolution Over Three Decades. Trop. Cons. Sci. 12: 1-15.

PÉREZ-CERVANTES, E., NAVARRO-ESPINOZA, E., ESTRADASALDÍVAR, N. A., ESPINOSA-ANDRADE, N., MELO-MERINO, S.M., RIVAS-SOTO, M. \& ÁLVAREZ-FILIP, L. 2017. Estado de conservación de los arrecifes de coral de la Península de Yucatán. GreenPeace, 24p.

RODRÍGUEZ-MARTÍNEZ, R.E. 2008. Community involvement in marine protected areas: The case of Puerto Morelos reef, México. J. Environ. Manage. 88(4):1151-1160.

SÁNCHEZ-QUINTO, A. \& FALCÓN, L.I. 2019. Metagenome of Acropora palmata coral rubble: Potential metabolic pathways and diversity in the reef ecosystem. PloS One. 14(8): e0220117.

SANTOS-MARTÍN, F., DEL OLMO, C.M., ALCORLO, P., TÍSCAR, S.G., GONZÁLEZ, B., GUTIÉRREZ, M.R.V.A. \& RUIZ, J.A.C. 2015. De la gestión de los recursos pesqueros a la gestión de los ecosistemas: La aproximación de los servicios de los ecosistemas aplicada a la gestión pesquera. Ambienta. 1(111): 74-87.

SEMARNAT - Secretaría de Medio Ambiente y Recursos Naturales. 2003. Compendio de Estadísticas Ambientales. México. 
SEMARNAT - Secretaría de Medio Ambiente y Recursos Naturales. 2006. Política Nacional de Desarrollo Sostenible para costas y oceanos. México.

SEMARNAT - Secretaría de Medio Ambiente y Recursos Naturales. 2016. Programa de Manejo Parque Nacional Costa Occidental de Isla Mujeres, Punta Cancún y Punta Nizuc. 234p.

SILVA, H., ROSAS, G., SECAIRA, F., MELLER, T. \& MENDOZA, M. 2019. Good Practices for Climate Change Adaptation. Sobrevive al cambio climático en Caribe. Catálogo de buenas prácticas de uso del suelo, manejo de paisaje y construcción en la zona costeira de Quintana Roo. Panorama partners.

SPALDING, M.D. RUFFO, S. LACAMBRA, C., MELIANE, I., HALE, L.Z., SHEPARD, C.C., BECK, M.W. 2014. The role of ecosystems in coastal protection: Adapting to climate change and coastal hazards. Ocean \& Coastal Management, 90: 50-57

SUTHERLAND, K. P., PORTER, J. W., TURNER, J. W., THOMAS, B. J., LOONEY, E. E., LUNA, T. P., MEYERS, M.K., FUTCH, J.C. \& LIPP, E. K. 2010. Human sewage identified as likely source of white pox disease of the threatened Caribbean elkhorn coral, Acropora palmata. Environmental Microbiology, 12(5): 1122-1131.

TALLIS, H., LEVIN, P.S., RUCKELSHAUS, M., LESTER, S.E., MCLEOD, K.L., FLUHARTY, D.L. \& HALPERN, B.S. 2010. The many faces of ecosystem-based management: making the process work today in real places. Mar. Policy. 34(2): 340-348.

TAYLOR, M.D., GASTON, T.F. \& RAOULT, V. 2018. The economic value of fisheries harvest supported by saltmarsh and mangrove productivity in two Australian estuaries. Ecol. Indic. 84: 701-709.

TEEB - The Economics of Ecosystems and Biodiversity. 2010a. Integrating the ecological and economic dimensions in biodiversity and ecosystem service valuation. The economics of ecosystems and biodiversity: ecological and economic foundations. Earthscan, London.

TEEB - Economics of Ecosystems and Biodiversity. 2010b. Mainstreaming the economics of nature: a synthesis of the approach, conclusions and recommendations of TEEB.
TRISURAT, Y., ALKEMADE, R. \& VERBURG, P.H. 2010. Projecting land-use change and its consequences for biodiversity in Northern Thailand. Environ. Manage. 45(3): 626-639.

UN - United Nations Organization. 2019. International Coral Reef Initiative. Analysis of Policies Related to the Protection of Coral Reefs: Analysis of Global and Regional Policy Instruments and Governance Mechanisms Related to the Protection and Sustainable Management of Coral Reefs.

VALIELA, I., BOWEN, J.L. \& YORK, J.K. 2001. Mangrove forests: one of the World's threatened major tropical environments. BioScience. 51(10): 807-815.

VÁZQUEZ-LULE, A.D., SANTOS-GONZÁLEZ, P. \& ADAME, M.F. 2009 Caracterización del sitio de manglar Nichupté, en Comisión Nacional para el Conocimiento y Uso de la Biodiversidad (CONABIO), Sitios de manglar con relevancia biológica y con necesidades de rehabilitación ecológica. Mexico City, Mexico: CONABIO.

WEIJERMAN, M., FULTON, E.A., KAPLAN, I.C., GORTON, R., LEEMANS, R., MOOIJ, W.M. \& BRAINARD, R.E. 2015. An integrated coral reef ecosystem model to support resource management under a changing climate. PLoS One. 10(12): e0144165.

WOODHEAD, A.J., HICKS, C.C., NORSTRÖM, A.V., WILLIAMS, G.J. \& GRAHAM, N.A. 2019. Coral reef ecosystem services in the Anthropocene. Funct. Ecol. 33(6): 1023-1034.

YÁÑEZ-ARANCIBIA, A., DAY, J.W. \& REYES, E. 2013. Understanding the coastal ecosystem-based management approach in the Gulf of Mexico. J. Coast. Res. 63(sp1): 244-262.

ZALDÍVAR, J.M., VIAROLI, P., NEWTON, A., DE WIT, R., IBAÑEZ, C., REIZOPOULOU, S. \& MURRAY, N. 2008. Eutrophication in transitional waters: an overview. Transitional Waters Monographs. 2(1): 1-78.

Received: $18 / 10 / 2019$

Revised: 10/05/2020

Accepted: 17/06/2020

Published online: $27 / 07 / 2020$ 